\title{
اثر التدريب على استراتيجيات للتعلم النشط في دافعية الانجاز ومهارات التدريس لاى طلبة قسم الحاسبات
}

أ.م.د. ميعاد جاسم السراي

الجامعة المستنصرية / كلية التربية

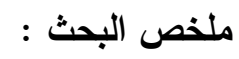

هدف البحث الى معرفة اثز التدريب على استراتيجيات للتعلم النشط في دافعية الانجاز ومهارات التذريس للمجموعة التجريبية ودافعية الانجاز ومهارات التذريس للمجموعة الضابطة في مادة المشاهدة والتطبيق (التربية العملية ) للمرحلة الرابعة في كلية التربية - قسم الحاسبات ولتحقيق هدفي البحث اعدت الباحثة خططا نعليمية وتدريبية للمجموعة التجريبية ومقياس لدافعية الانجاز وبطاقة ملاحظة مهارات التدريس تم تطبيقهما على مجموعتي البحث بعد انتهاء التجربة .وقد نكونت عينة

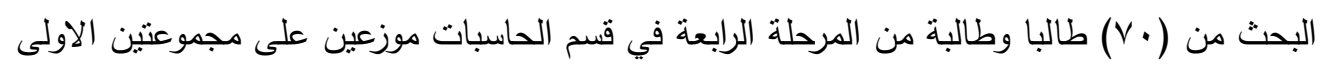
تجريبية (0ب) طالبا وطالبة درست وتدربت وفق استراتيجيات للتعلم النشط والثانية ضابطة (مب) طالبا وطالبة درست وتدربت وفق الطريقة الاعتيادية لمادة المشاهدة والتطبيق ، وقد اعتمد البحث على المنهج شبه التجريبي وقامت الباحثة بضبط جميع العوامل الغير تجريبية (العدر الزمني ، مدرس ولئ المادة، المادة الدراسية ،معدل التحصيل السابق في مادة مناهج وطرائق التدريس، دافعية الانجاز )بحيث يعزى ما قد يحدث من فروق إلى المعالجة التجريبية دون غيرها ـ وبعد انتهاء فترة التجربة طبقت الباحثة مقياس الدافعية وبطاقة الملاحظة على مجموعتي البحث ،وقد اشارت نتائج التجربة

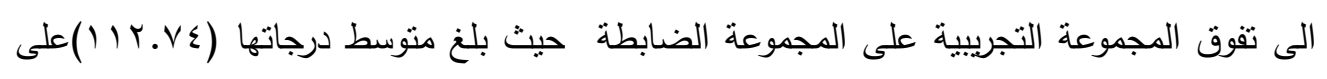
مقياس دافعية الانجاز واعطت هذه النتيجة فرقا ذات دلالة إحصائية عند مستوى دلالة هـ. . . ولصالح المجموعة التجريبية كما أظهرت نتائج البحث ان هناك فروقا في منوسط درجات بطاقة

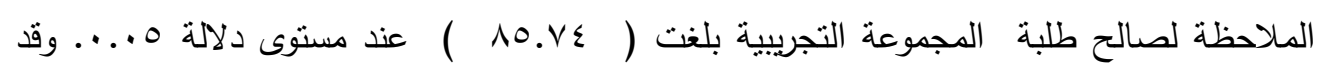
اوصت الباحثة باستخدام استراتيجيات التعلم النشط في التدريس الجامعي كما اوصت بإقامة دورات

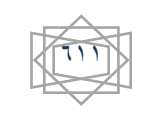




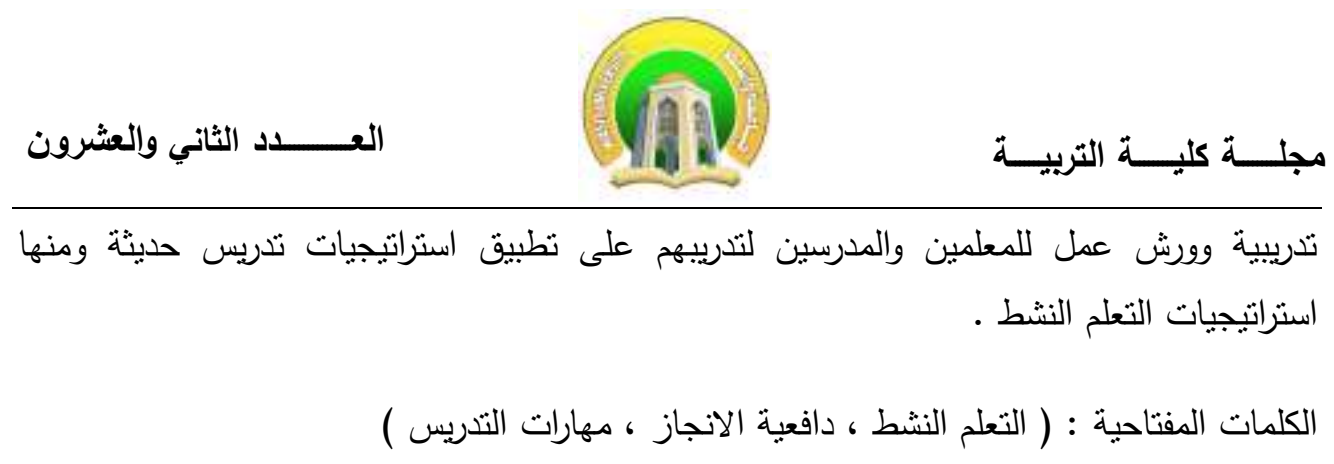

\section{Summary Research:}

The research aim is to know the effect of active learning strategies on achievement motivation of fourth stage students in computer department and Teaching Skills ,the research sample was 70 from the fourth stage divided on two groups, experimental (35) students and controller group (35) students, to achieve the objectives, a training program and achievement motivation and teaching skills scales were prepared, and by using T-TEST the results shows statistically significant difference between two groups in favors of the experimental group in both variables.

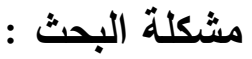

ان النظرة الى عملية التعليم قد تغيرت فأصبحت تعد تتظيما لعملية التعلم يوجه فيها الاهتمام الى الى الحاجات المختلفة للمتعلمين ،ولم يعد مطلوبا من المعلمين اتقان المادة الدراسية فقط والسيطرة عليها

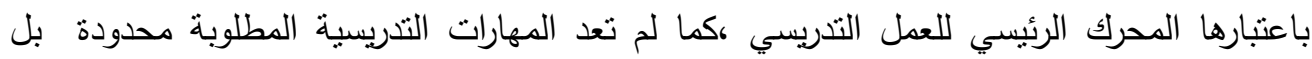

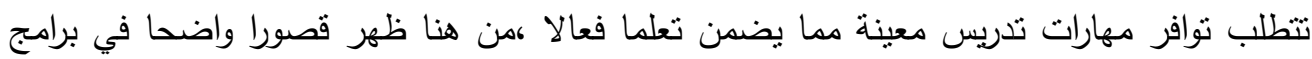

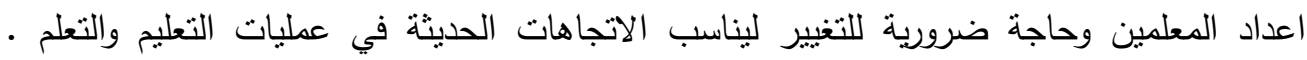

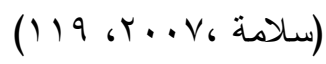

وتتطلب معايير جودة التعليم التي تتادي بها الهيئات العالمية والوطنية كالمجلس الوطني لاعتماد المعلمين وتأهيلهم (1999 مCATE ) مراعاة الفروق الفردية في انماط التعلم بين المتعلمين فلكل

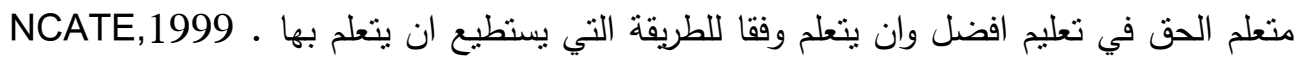
( ,pp7-9)

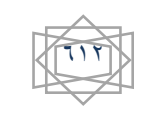


من جهة اخرى اتفق معظم التربويون على ان مفهوم دافعية الانجاز عاملا مهما في توجيه السلوك الهو

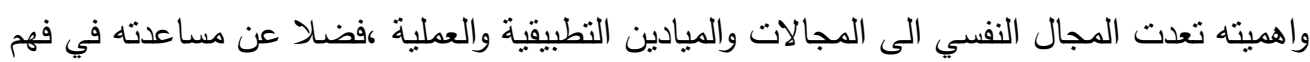

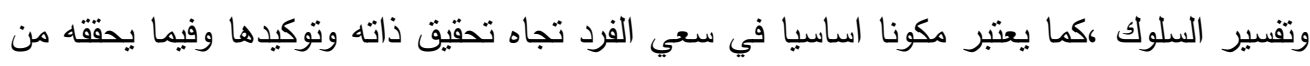

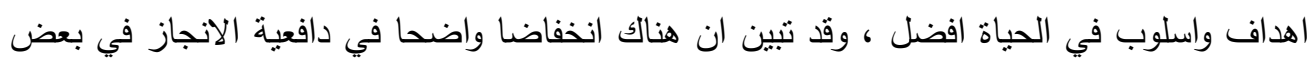

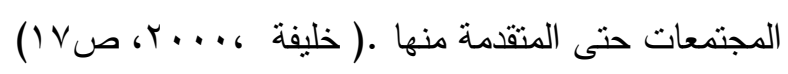

والتعلم النشط من المفاهيم الحديثة التي اجتاحت القطاع التعليمي العالمي والعربي لما لها من دور في التربية الفعالة القائمة على حث المتعلم على المثابرة في الانشطة والرغبة في الاداء الجيد و الاستمرار

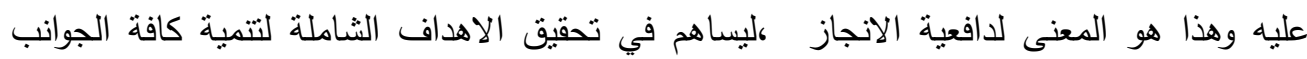

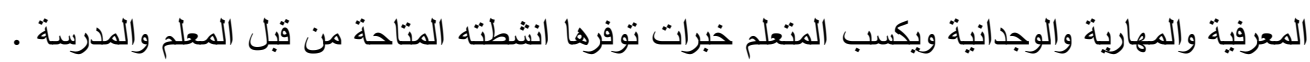

وقد اكدت الادبيات التربوية اهمية ان يكون المتعلم اكثر من مستمع فعليه ان يقرأ ويكتب ويحل

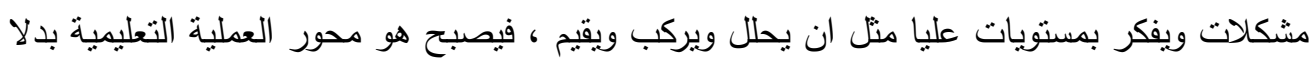
من المعلم ،وهذا يحدث عندما يتفاعل المتعلم مع المادة العلمية وينلقى التتجيع على المناقتشة والاكتثاف وحل المشكلات والتفكير الناقد .

ومن منطلق اهمية التعلم الفعال والتعلم النشط ودورهما في تتمية قدرات المتعلم فقد اولت الدراسات

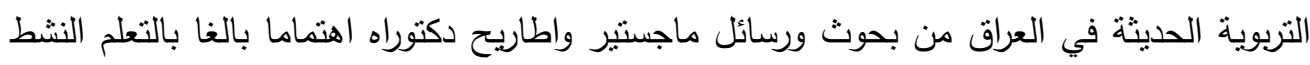

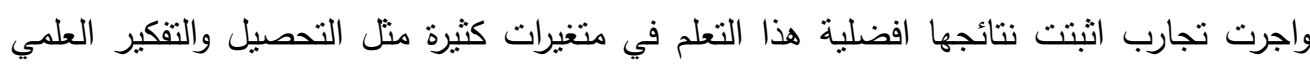

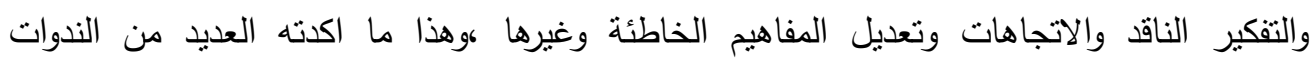

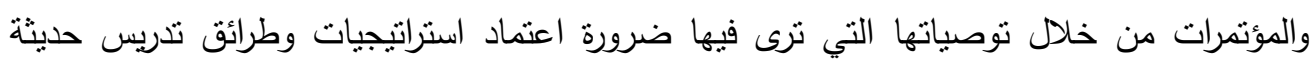
تربط التعلم النظري بتطبيقاته العملية وتجعل الطالب محورا للعملية التعليمية ـ (مؤتمر الجامعة فئات

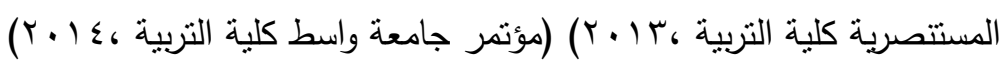

وبالرغم من ذلك ترى الباحثة ضعف وتدني واضح في دافعية الانجاز وفي مهارات تدريس الطلبة -

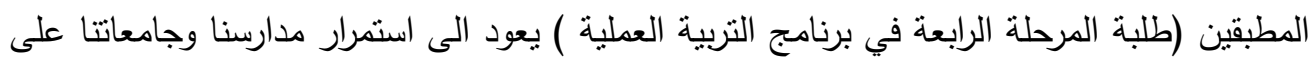

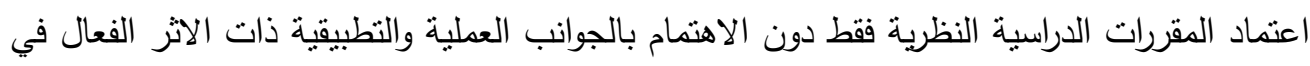

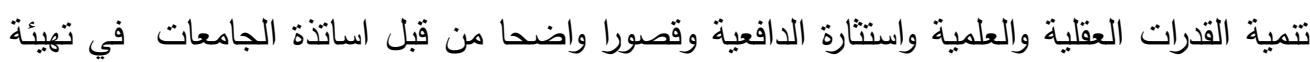

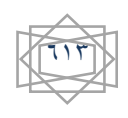


البيئة الصفية المناسبة لتعلم نشط وفعال وذلك من خلا عملها وخبرتها كباحثة وتدريسية في

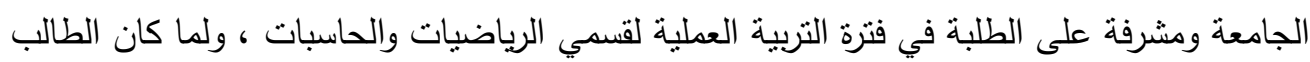

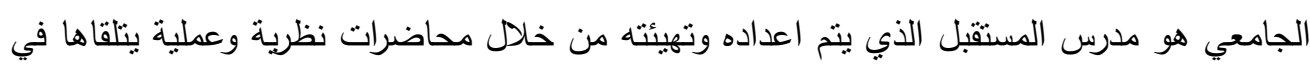

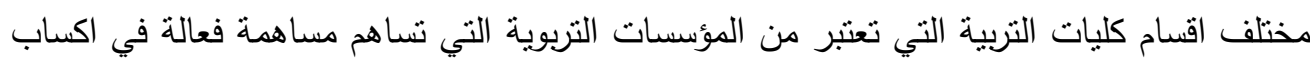

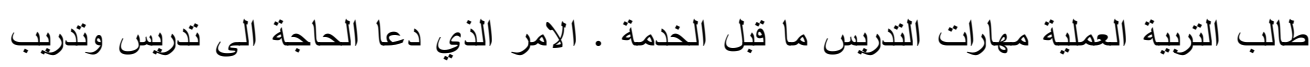

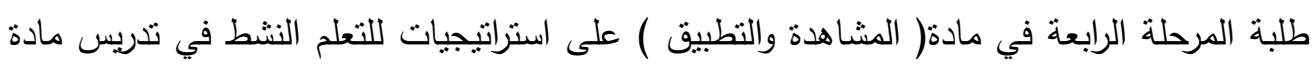

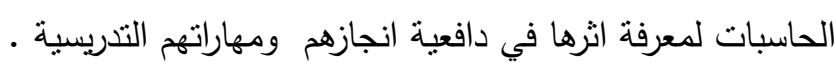

لذلك يمكن تحديد مشكلة البحث في التساؤل التالي : ما اثز تدريب طلبة المرحلة الرابعة(طلبة التربية العملية ) في قنم الحاسبات على التى استراتيجيات

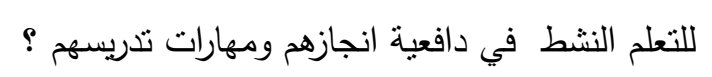

\section{أهمية البحث : n}

لم يقف اثر الحاسوب عند الثورة التي احثنها في كافة المجالات في الاعوام الاخيرة بل تعداها

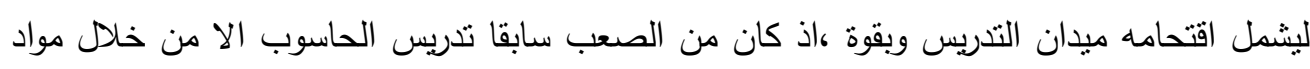

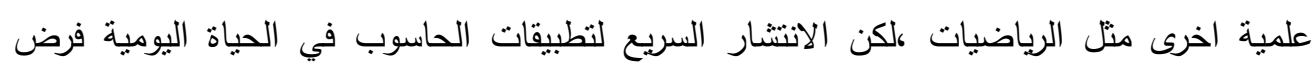

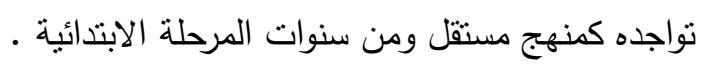

ويستخدم الحاسوب كمادة تعليمية سواء اكان ذلك في نطاق رفع الامية التكنولوجية ام في

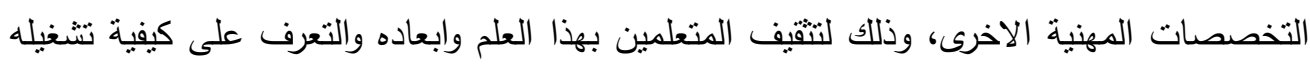

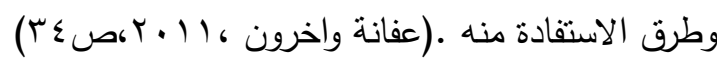

وهناك من اقترح تدريس الحاسوب كمنهج مستقل بدءا من الحلقة الثانية من التعليم الأساسي أب من

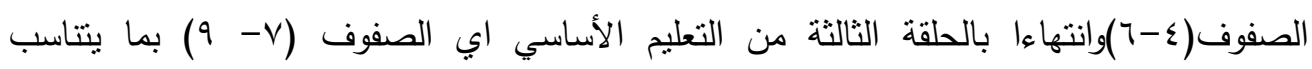

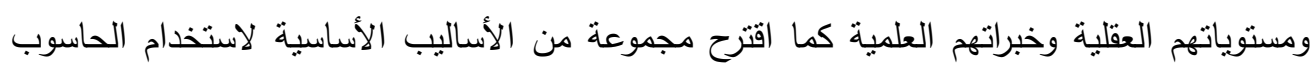

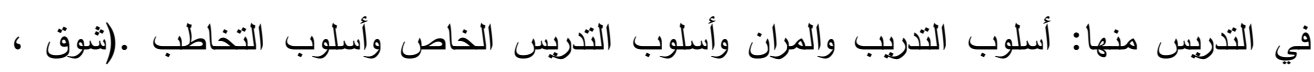
(₹ro صنr.)

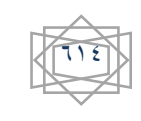


واعتمادا على هذا التوجه الحليث من قبل المتثمين بمجال التربية والتعليم اصبح من الضروري الاهتمام بإعداد كادر من المعلمين والمدرسين لمادة الحاسوب بشكل منفصل في كلئل فليات التربية وكليات المعلمين وهذا ما حصل فعلا في معظم جامعات الدول العربية .

ولما كانت كل امة نتظر الى اصلاح التعليم بوصفه احد اهم الوسائل التي تطمح من خلالها الى بناء

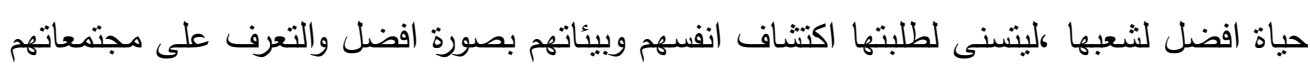

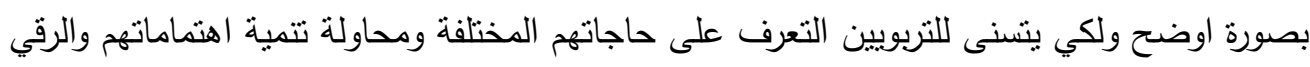

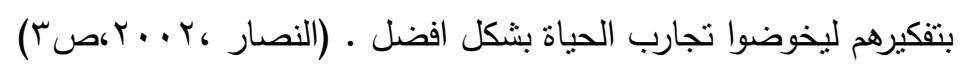

اتفق معظم التربويين والمشتغلين في مجال اعداد المعلمين على تغير ادوار المعلم واختلاف كفاياته

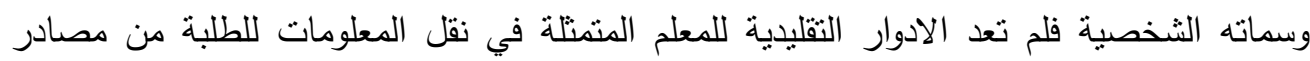

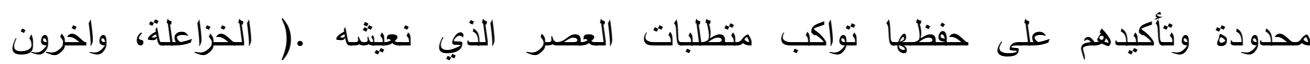

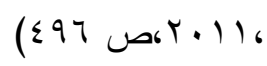

واذ يتميز هذا العصر بكونه عصر العلم والتكنولوجيا ،الذي نحتاج فيه الى تربية الفرد تربية علمية

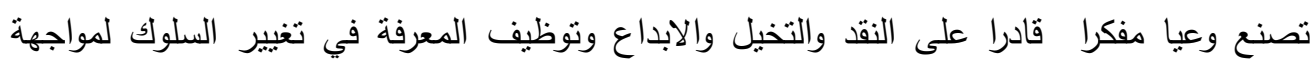
التحديات المستقلية كان لابد لمناهج اعداد المعلم ان تأخذ بنظر الاعتبار هذه الادوار الجديدة للمعلم.

وان عملية تطوير مهارات وقدرات المتعلمين لا تأتي من اعتماد مناهج حديثة فقط ،بل لابد من

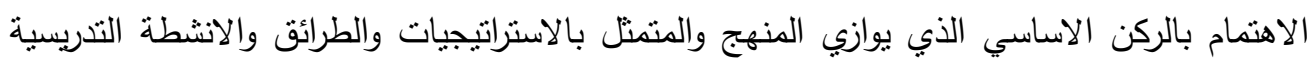

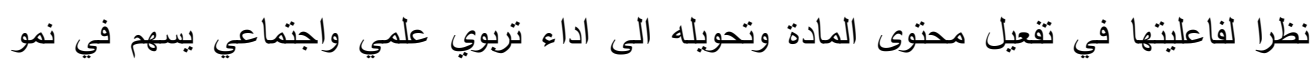

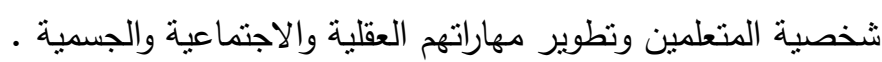

كما ان استخدام طرائق التذريس المستتدة على فاعلية المتعلمين وايجابية كل واحد منهم وتلك التي

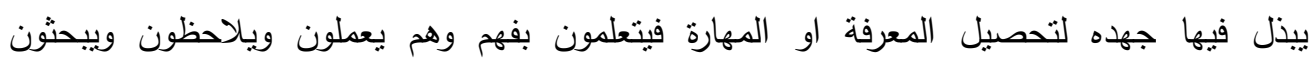

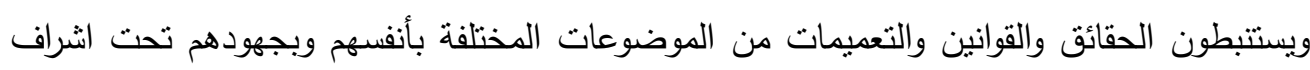
وتوجيه المدرس يجعل الفاعلية والنشاط يحل محل التلقين والسلبية كما يجعل المعرفة والمعلومات

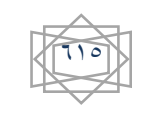


والحقائق العلمية مصدرا ينتفع بها مستقبلا كذلك يصبح المدرس مرشدا موجها ومشجعا للميول

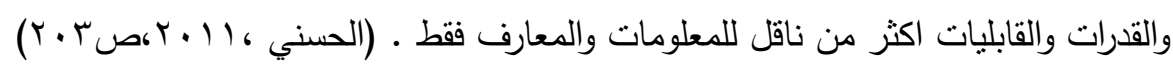

وان اهمية طرائق التدريس الحديثة تمثلت بكونها جعلت المتعلم في المقام الاول بين عناصر العملية

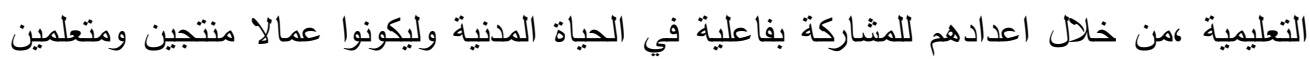

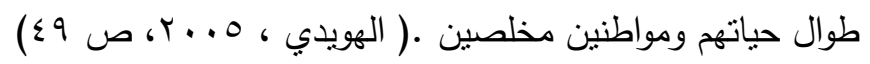

ويؤكد معظم التربويين على ان تحويل التعلم الاعتيادي الى تعلم نشط داخل غرفة الصف يزيد من

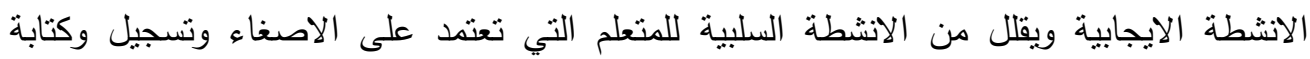

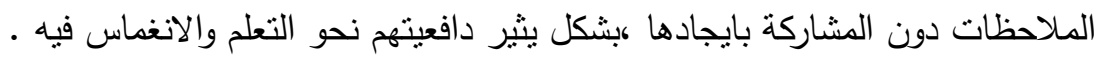

(Carroll \&Leander,2001,p33).

وكون طالب التربية العملية (طالب المرحلة الرابعة في كليات التربية ) معلما مستقبليا ومتعلما في

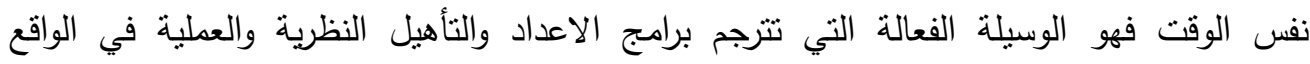

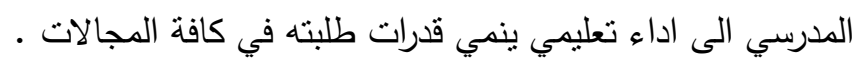

واهداف البرامج التعليمية والتدريبية متعددة ومختلفة فهي تحقق للمتعلمين(طلبة التربية العملية) انجازات فكرية عالية وقيم انسانية تتمثل بمساعدة الاخرين (اي طلبتهم )وتزويدهم بالتغذية الراجعة

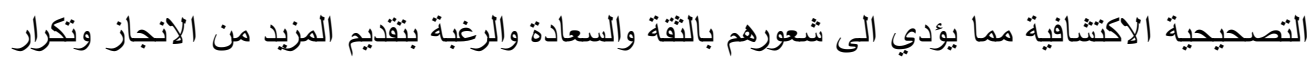

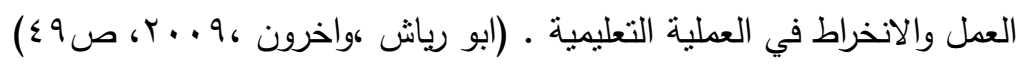

وقد اوصى بعض التربويين بضرورة استثمار نتائج البحوث التربوية في نطوير برامج اعداد المعلمين

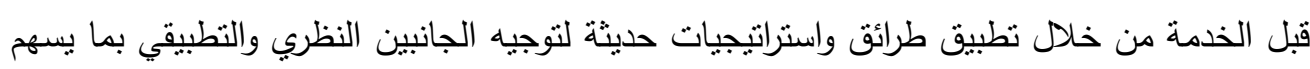

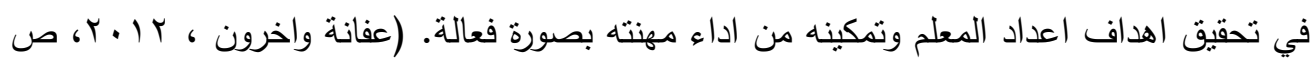
(rov

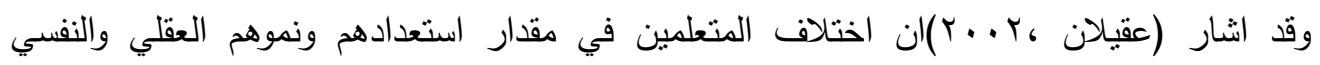

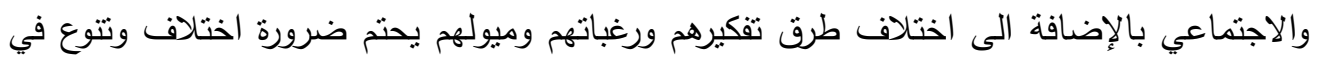

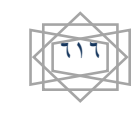


تقديم نماذج وطرائق تدريس نوفر لهم فرصا وظروفا متغيرة من شأنها ان تساعدهم في اكتساب

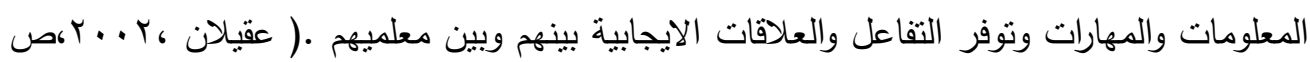

وحتى يكون التدريس فعالا عليه ان بستجيب لأنماط التفكير الخاصة بالمتعلم وان يكون تعلمه ذي

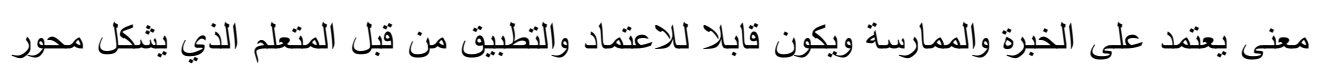

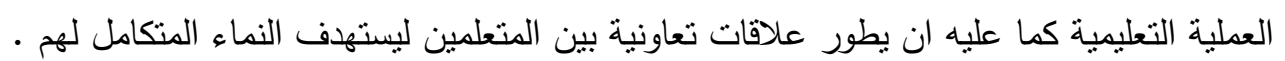

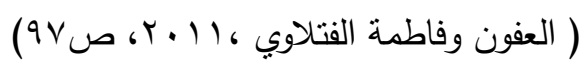

والتندريس الفعال هو نشاط تعليمي هادف تتم من خلاله توفير بيئات تعليمية تكون بمثابة مزارع لتتمية

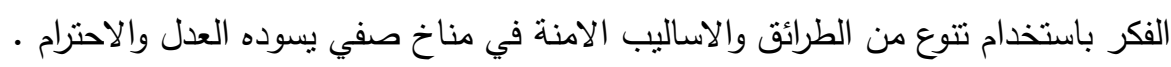

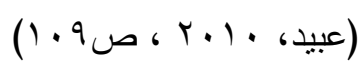

كذللك تعتبر دافعية الانجاز شرط اساس في عملية التعلم الجيد وهذا ما اكدته نتائج دراسات عديدة

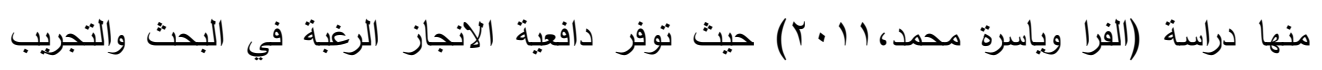

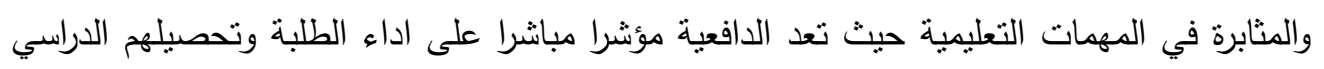

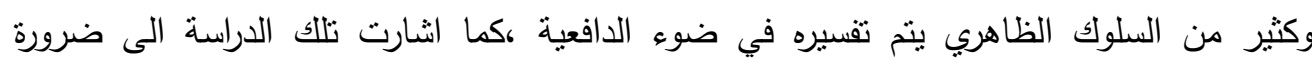

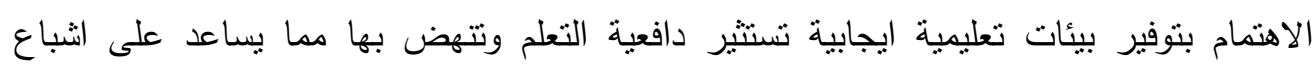

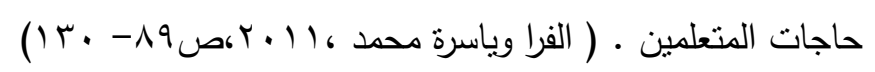

والاستتاد الى الدافعية كأحد عوامل التعلم يجعل التعلم نشطا وفعالا وحيويا ويطرد الملل ويقرب طرق

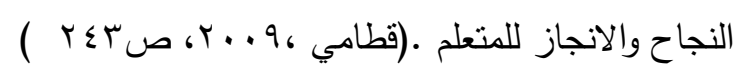

وبهذا يكون التدريس الفعال هو نعلما نشطا يوفر فرصا عديدة للتتعلمين لإكسابهم خبرات توسع

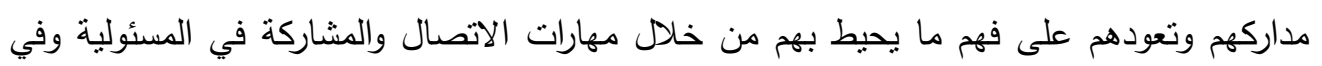
اتخاذ القرار في بيئة داعمة وامنة ومحفزة على الاكتثاف ومثنيرة لدافعية الانجاز والرغبة في اداء

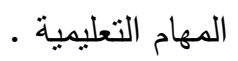


ان استراتيجيات التعلم النشط قد انبتقت من مضامين النظرية المعرفية ،وان اهداف هذه النظرية قد

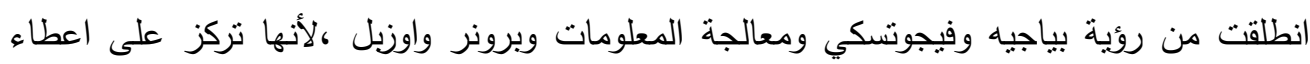

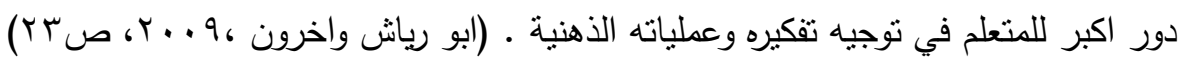

وهناك مجموعة من الاهداف يحقهها التعلم النشط منها : ()تعرف المعلم واكسابه احدث اساليب التعلم

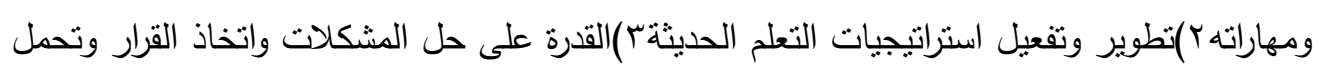

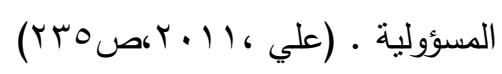

اما مميزات النعلم النشط بالنسبة للطالب - المعلم فهي عديدة منها : ())شرالك المتعلم بفاعلية مع

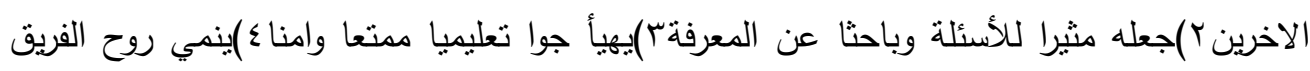

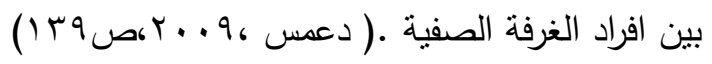

واستراتيجيات التعلم النشط كثيرة ومتعددة منها : الحوار والمناقثة - التعلم التعاوني -لعب الادوار - التئل العصف الذهني- حل المشكلات-الخرائط المعرفية -الاسئلة- التعلم الذاتي- تعلم الاقرانالاكتثاف.

ومن ابرز فوائد التعلم النشط التي تربطه بدافعية الانجاز : (1)توصل المتعلم الى حلول ذات معنى

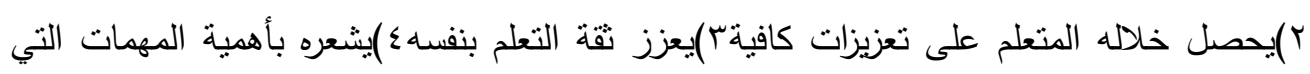

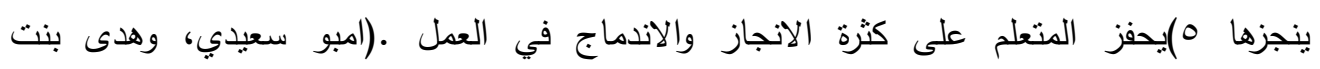

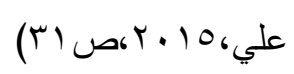

$$
\text { وعليه تتحدد اهية البحث الحالي من خلال اهمية كل من : }
$$

1- تدريب طلبة المرحلة الرابعة في كليات التربية (في مادة المشاهدة والتطبيق) كونه الاجراء الضروري لتحويل الجانب النظري الذي تلقاه خلال سنوات الدراسة الى الجانب التطبيقي

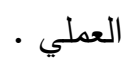

r- التعلم النشط باستراتيجياته الدختلفة التي نساير الاتجاهات الحديثة للعملية التعليمية التعلمية وتوفر بيئة صفية فعالة .

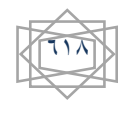




\section{العـــــــد الثاني والعشرون}

\section{مجلـــة كليـــة التربيــة}

r- دافعية الانجاز كونه عاملا مهما من عوامل نجاح المتعلم والمتدرب وشرط اساسي في

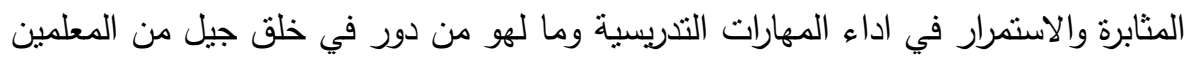
والمدرسين الفاعلين في كل التخصصات. ع - مهارات التدريس واهمية تتميتها وفق استراتيجيات حديثة تتقل المتعلم والمتدرب الى ادوار

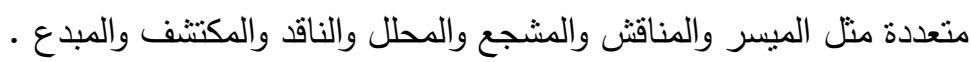
ه- مادة الحاسبات باعنبار دراستها توفر قدر مناسب من النقافة والمهارات التي تعد المتعلم

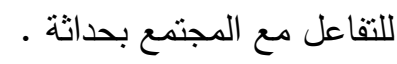
צ- وضع تصور مستقبلي لمفردات مادة المثاهدة والتطبيق وطرائق تدريسها في قسم الحاسبات

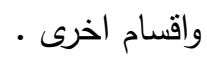

\section{أهداف البحث : يهدف البحث الى :}

1- التعرف على اثر التدريب على استراتيجيات للتعلم النشط في دافعية انجاز طلبة المرحلة

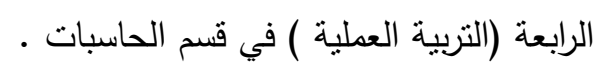

r- التعرف على اثر التدريب على استراتيجيات للتعلم النشط في مهارات التدريس لدى طلبة

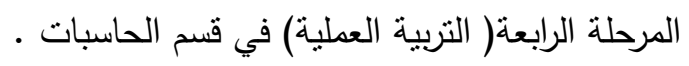

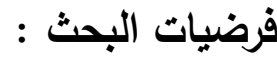

ו- لا يوجد فرق ذا دلالة إحصائية بين متوسط درجات المجموعة التجريبية والمجموعة

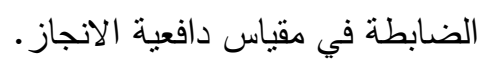

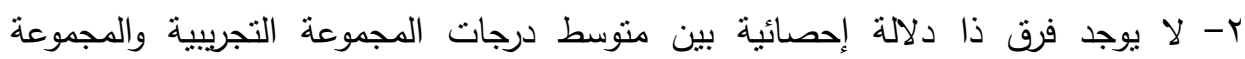

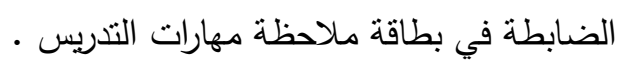

$$
\text { حدود البحث : يقتصر البحث الحالي على :- }
$$

1- طلبة المرحلة الرابعة في قسم الحاسبات -الدراسة الصباحية -كلية التربية - الجامعة

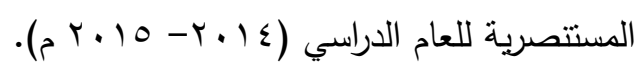

r- اقتصر التدريس والتدريب على مادة المشاهدة والتطبيق في الفصل الدراسي الاول . 


\section{مجلـــة كليـــة التربيــة}

r- حدد البحث عشرة استراتيجيات تم تدريسها والتدريب عليها في المجموعة التجريبية

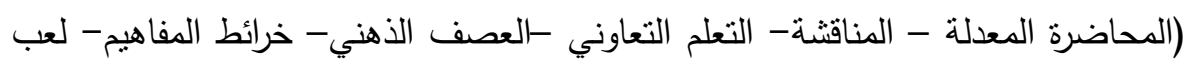

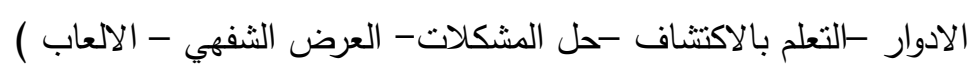

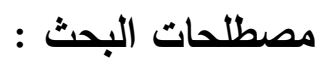

التطلم النشط : (Active learning) عرفه (1991, Bonwell \& Eison ) بانه اناحة الفرصة للمتعمين في المشاركة في الانشطة التي نتجعهم على التفكير والتعليق على الموضوعات فهم ليسوا مستمعين فقط بل

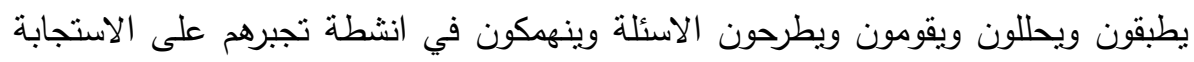
للأفكار المطروحة وكيفية استخدامها في مواقف تعليمية جديدة . Bonwell\&Eison (, 1991,p50

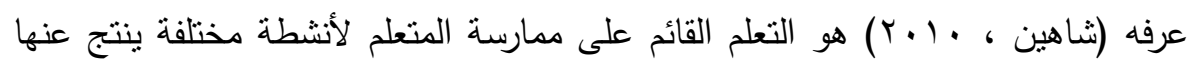

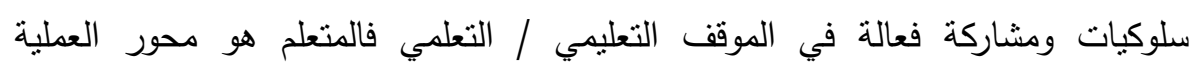

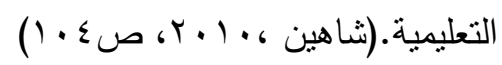

التعريف الاجرائي لاسترايجيات التعلم النشط :هو مجموعة الخبرات التربوية المنظمة بطريقة

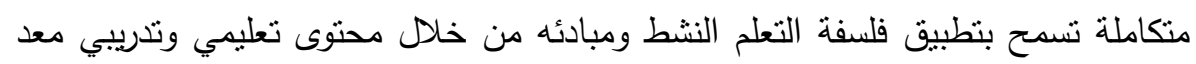
لهذا البحث يقدم للطالب في المجموعة التجريبية اثثاء فترة المشاهدة والتطبيق.

(Achievement motivation): دافعية الانجاز

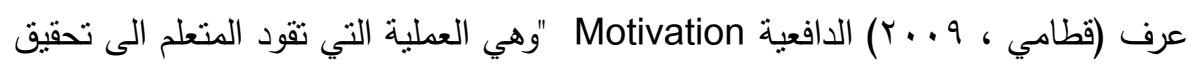

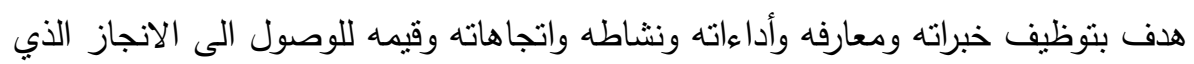

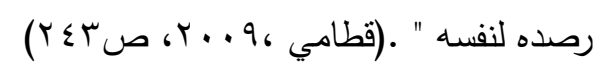

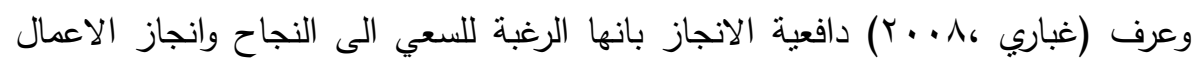

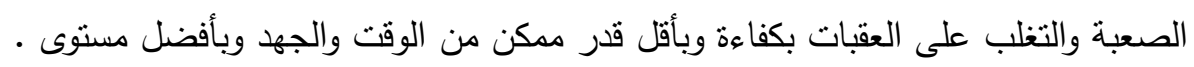

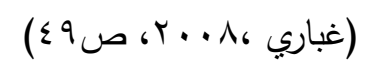

التعريف الإجرائي لادفعية الانجاز :هي سمات نفسية وسلوكية يسعى طالب التربية العملية

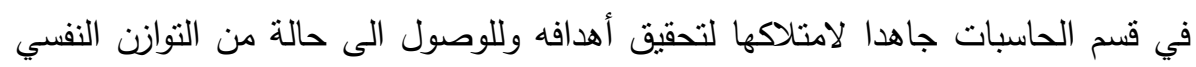

\section{迹}




\section{العـــــــد الثاني والعشرون}

\section{囚}

\section{مجلـــة كليـــة التربيــة}

والمعرفي والاجتماعي أثناء أداءه لمهامه التدريسية متمثلة بالدرجات التي يحصل عليها بعد استجابته لفقرات المقياس المعد لهذا البحث.

\section{(Teaching Skills): مهارات التدريس لونئه}

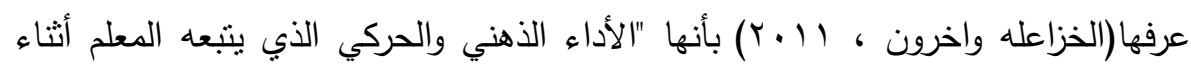

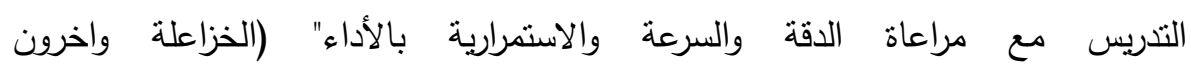
(10) م 1) 1)،

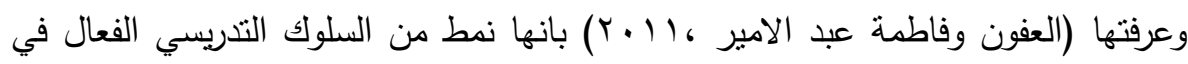
تحقيق اهداف محددة بصورة استجابات عقلية او لفظية او حركية او عاطفية تتكامل فيها

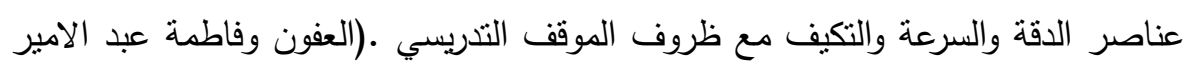
(9V Tr. 1)،

التعريف الاجرائي لمهارات التدريس : هي الاجراءات والاداءات التي يقوم بها طالب التربية

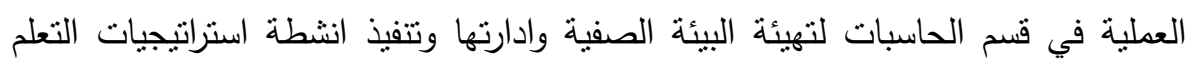
النشط وتقويمها متمثلة بالدرجات التي يحصل عليها بعد استجابته لفقرات بطاقة الملاحظة

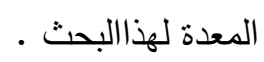

\section{الاسرات السابقة : الدابة}

دراسة (الفرا وياسرة محمد، 1) ب (ب) هدفت الدراسة الى التعرف على اثز استخدام بعض استراتيجيات

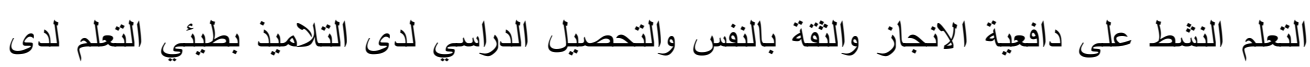

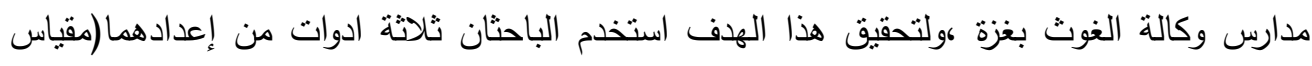

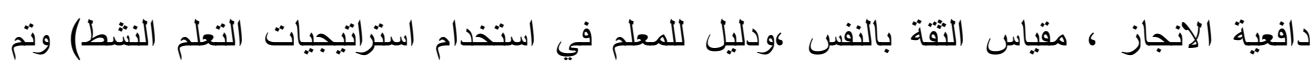

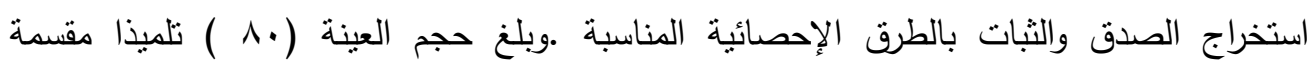

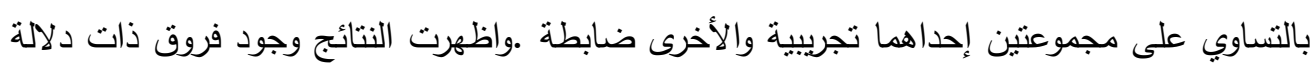

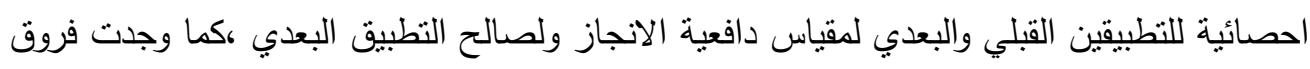

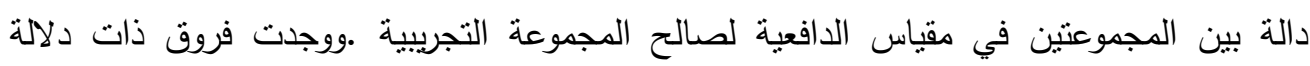

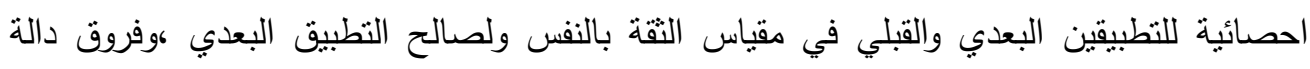

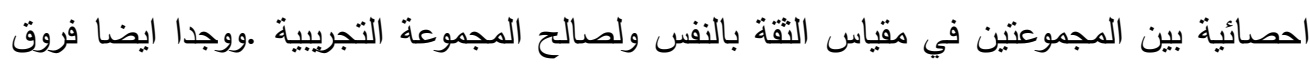

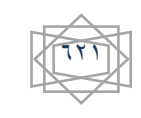


دالة احصائيا في اختبار اللغة العربية والرياضيات في التطبيقين البعدي والقبلي ولصالح التطبيق

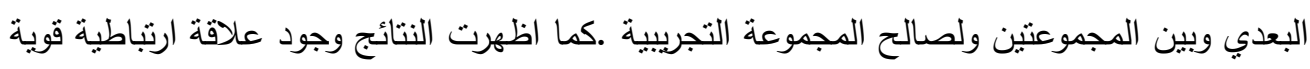

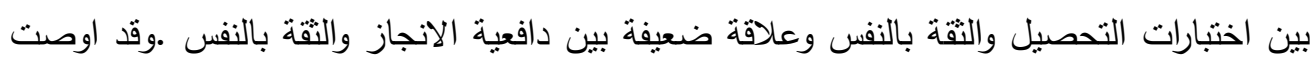

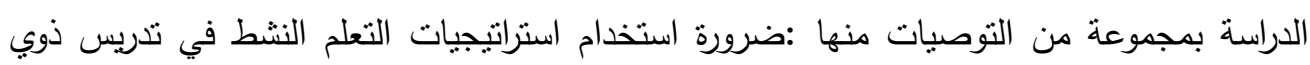
الفئات الخاصة .

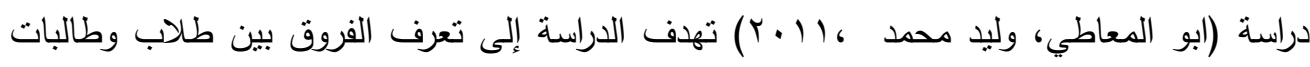

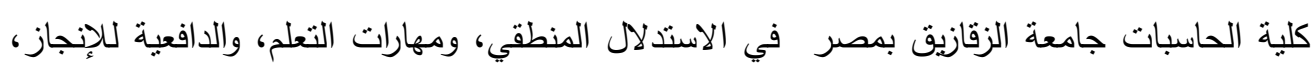

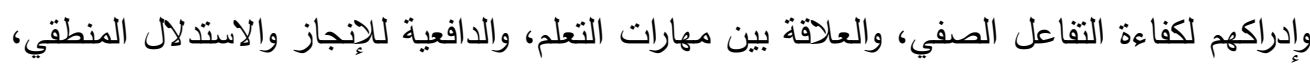

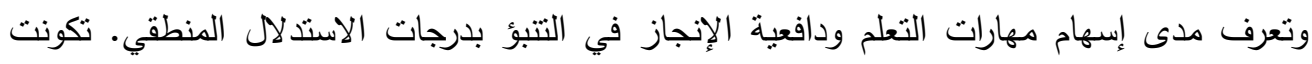

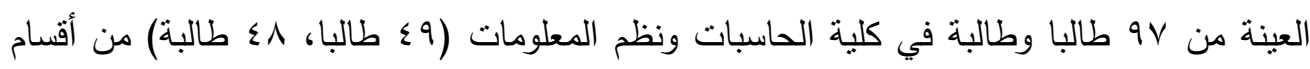

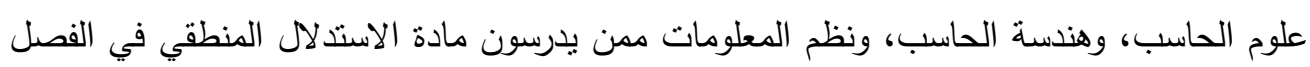
الدراسي الأول. تم استخدام مقياس مهارات التعلم، ومقياس دافعية الإنجاز ، ومقياس التفاعل الصفي.

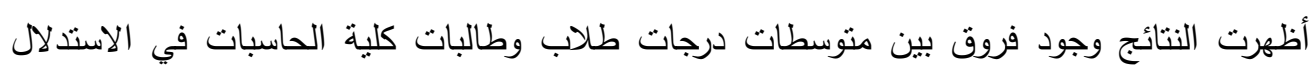

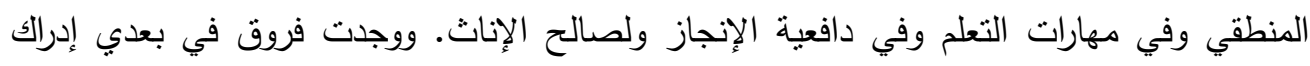

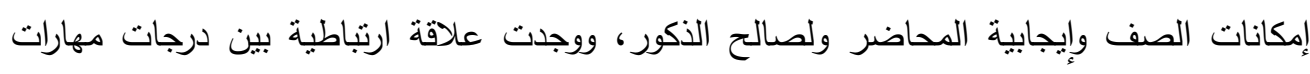

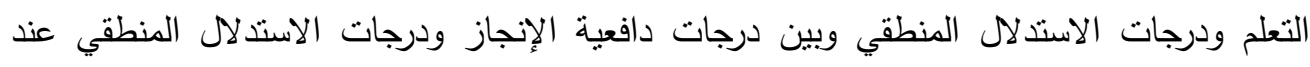

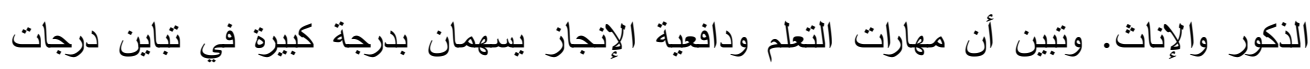
الأفراد في الاستخلال المنطقي.

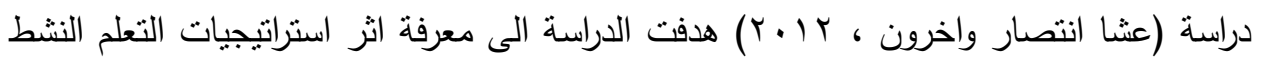

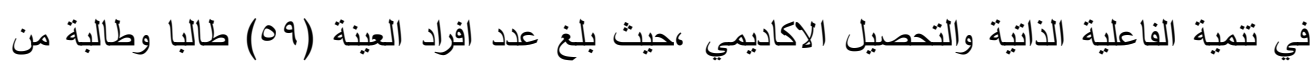

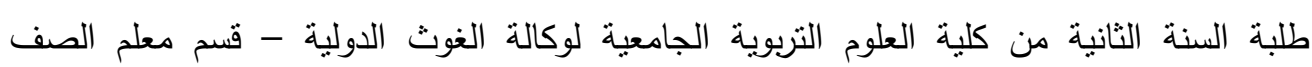

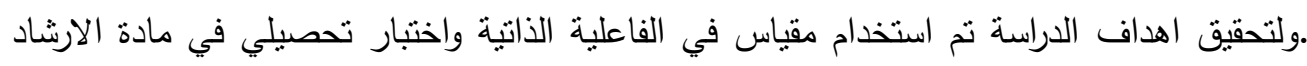

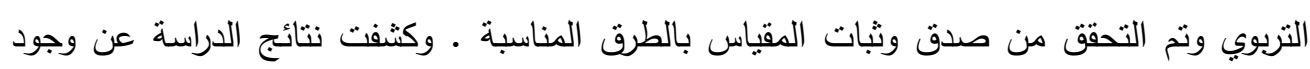

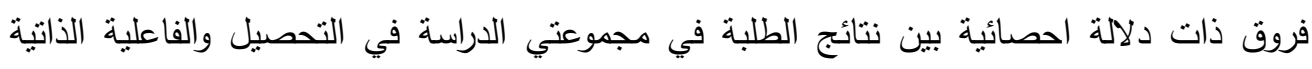

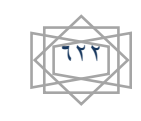




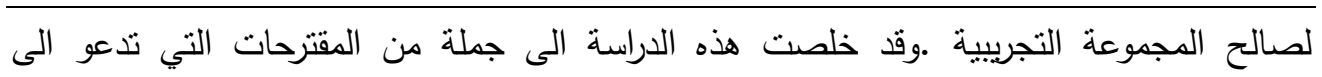

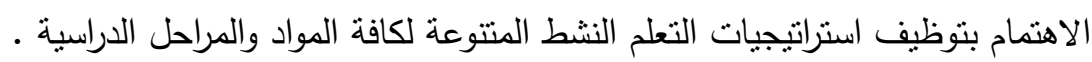

دراسة (مسعد ،شكري مسعد راضي ، Y. Y. هدفت الدراسة الحالية للتعرف إلى فاعلية استخدام

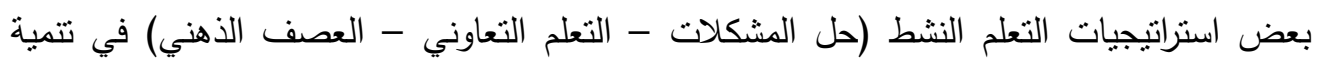
التفكير الناقد في الرياضيات لدى تلاميذ الصف الأول الإعدادي بالقاهرة ـ تكونت العينة من 97

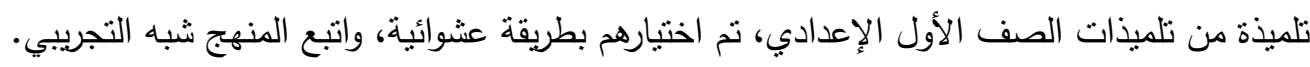

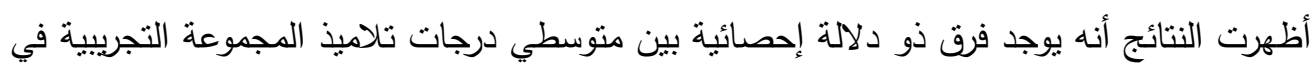

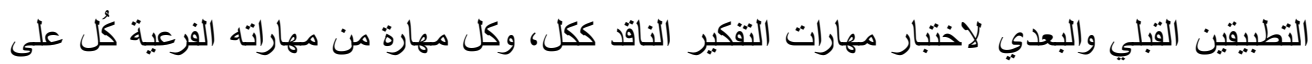

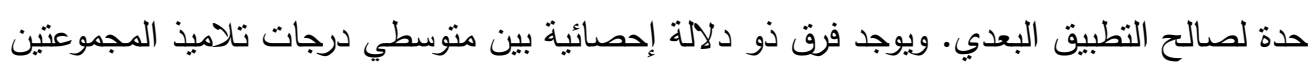

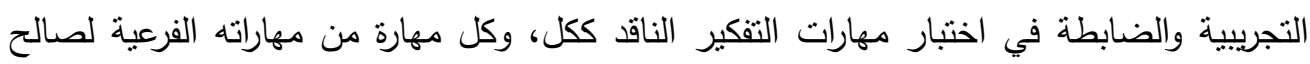
درجات تلاميذ المجموعة التجريبية .

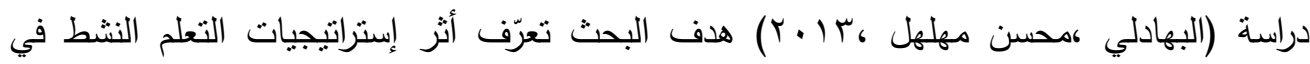

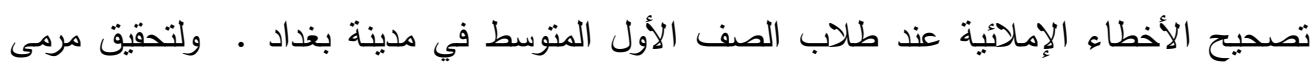

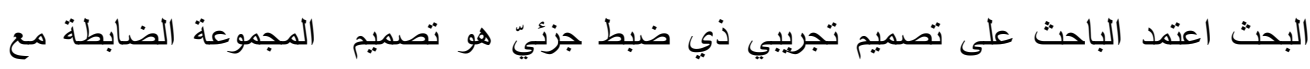

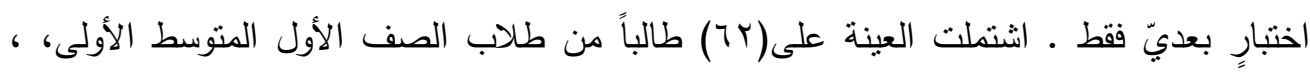

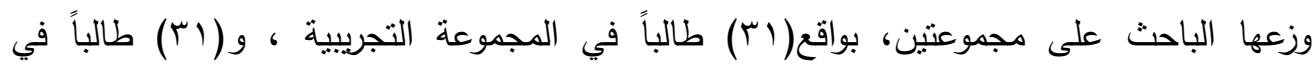

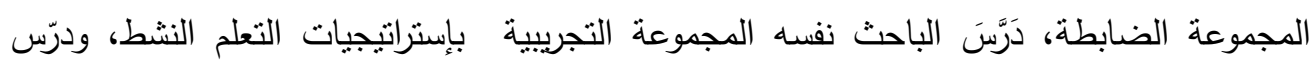

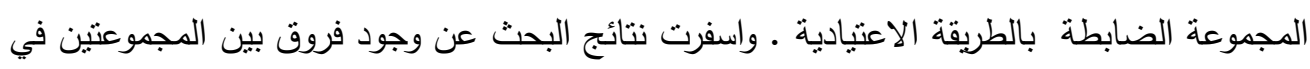

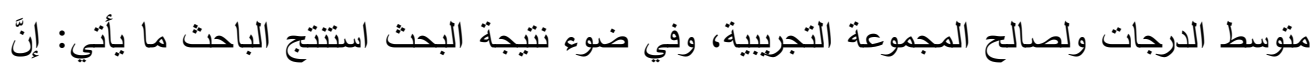

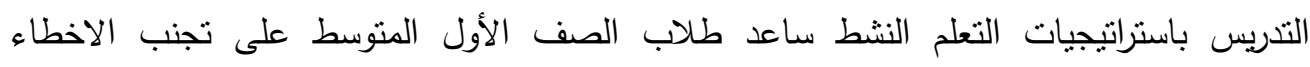

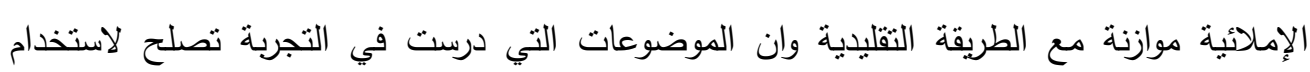

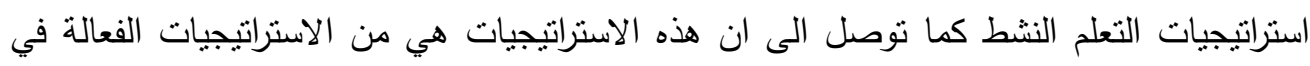




\section{إجراءات البحث :}

منهج البحث : لما كان البحث يدرس اثر المتغير التجريبي(استراتيجيات التعلم النشط)على متغيرات

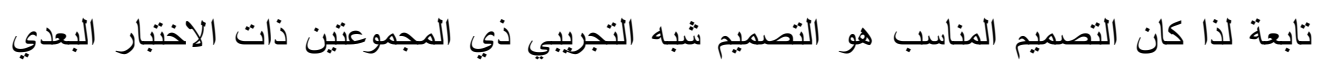

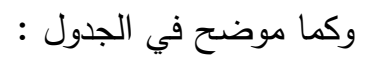

جدول (1) تصميم البحث

\begin{tabular}{|c|c|c|c|c|}
\hline الاداة & المتغير البعدي & المتغير المستقل & & المجموعة \\
\hline 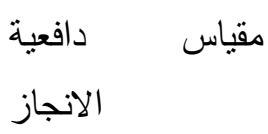 & دافعية الانجاز & النشتراتيجيات $\quad$ التعلم & المجموعتين & التجريبية \\
\hline مهارات التدريس & مهارات التدريس & البرنامج الاعتيادي & & الضابطة \\
\hline
\end{tabular}

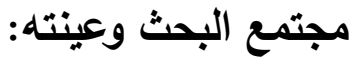

ان مجتمع البحث الحالي هو طلبة الجامعة المستصرية - كلية التربية قسم الحاسبات المرحلة

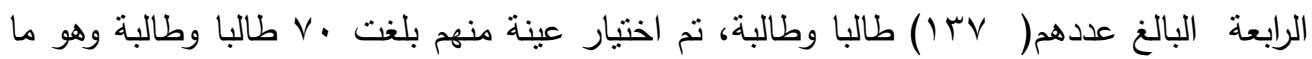

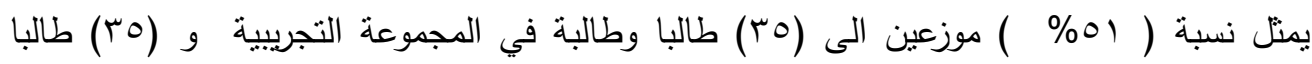

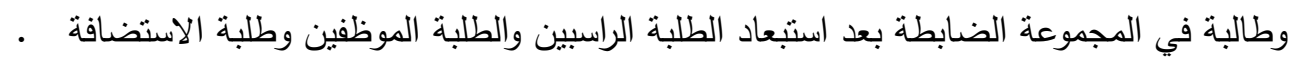

\section{أدوات البحث:}

للا كانت اهداف البحث الحالي تتمثل في معرفة اثر استخدام استراتيجيات التعلم النشط على دافعية الانجاز ومهارات التدريس فقد نم بناء اداتي البحث المتمثلة في مقياس الدافعية للانجاز وبطاقة

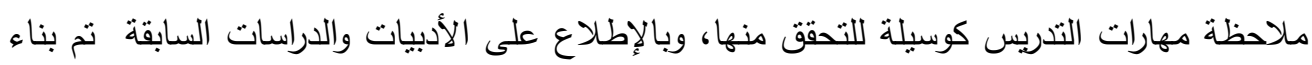

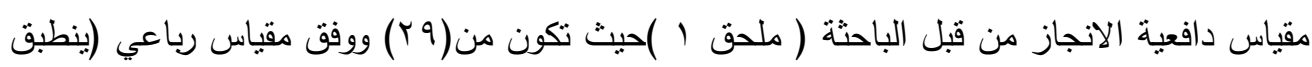


عليّ بشكل كبير، ينطبق عليّ بشكل منوسط، ينطبق عليّ بشكل قليل، لا ينطبق عليّ ) وتم تحديد

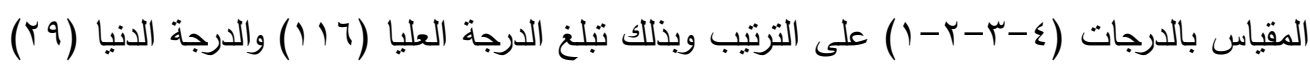
• اما الأداة الثانية(بطاقة مهارات التدريس) فقد نم بنائها ايضا بعد الاطلاع على الادبيات والدراسات السابقة فأصبحت الاستمارة متكونة من (بr) فقرة موزعة على اربعة مجالات ( مجال البيئة الصفية

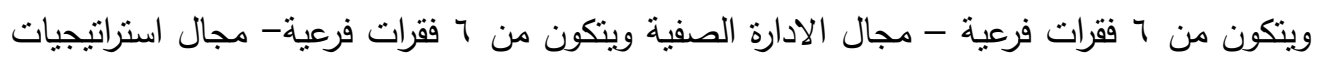
التعلم النشط ويتكون من با فقرة فرعية - مجال التقويم ويتكون من ^ فقرات فرعية) اما درجة توافرها ومستوياته فقد حددت ثلاث مستويات ( متحقق بدرجة كبيرة- متحقق بدرجة متوسطة - متحقق بدرجة قليلة) وتم تحديد المقياس ( (-r-1 ) لهذه المستويات على الترتيب (ملحق r) ) . وبذلك تبلغ الدرجة العليا على الاستمارة (79) والدرجة الدنيا (Yr) • ولكي يكون هذان المقياسان مناسبان لمجتمع البحث وعينته تم عرضهما على خبراء في طرائق التدريس وعلم النفس التربوي لابداء ارائهم حول صلاحية الفقرات لقياس السمة المطلوبة وحول تحديد الدرجة المناسبة لكل مستوى من مستويات توافرها لتحقيق الصدق الظاهري، كما تم حساب ثبات مقياس الدافعية باستخدام معادلة الفا كرونباخ مناخ

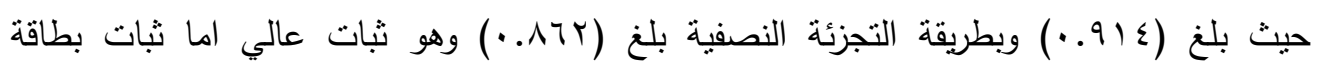
الملاحظة فقد نم حساب ثباتها من خلال عدد مرات الاتفاق والاختلاف بين مشاهدة الباحثة وزميلة لها في قسم الرياضيات* لعدد من الطلبة اثتاء التطبيق الميداني من خارج العينة وقد استخدمت

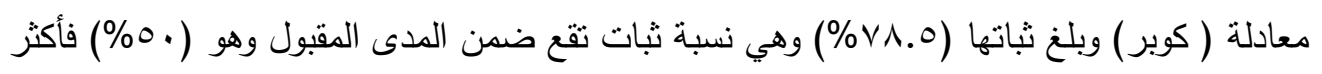

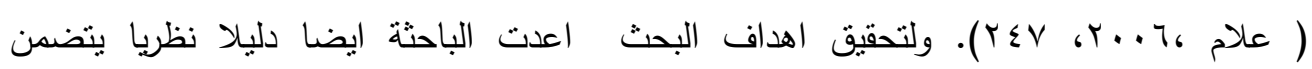
استراتيجيات التعلم النشط التي طبقت في محاضرات مادة المشاهدة والتطبيق وخطوات تتفيذها من قبل الباحثة للمجموعة التجريبية ووفق الجلسات الاسبوعية الموضحة في الجدول التالي : 


\section{مجلــــة كليــــة التربيــــة}

جدول (Y) توصيف محاضرات مادة المشاهدة والتطبيق للمجموعة التجريبية

\begin{tabular}{|c|c|c|c|c|}
\hline 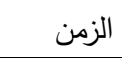 & الاسلوب التدريبي & الطريقة & المحتوى & الاسبوع \\
\hline • 9 دقيقة & فردي & المحاقثة & 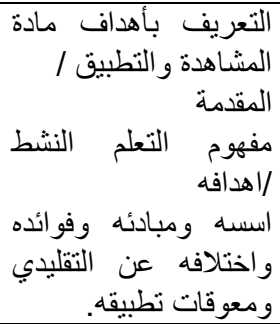 & الاول r/R/. \\
\hline ه دقيقة & فردي - جماعي & المناقشة التريس المصغرة & استراتيجيتي المحاضرة & الثاني \\
\hline ه دقيقة & فردي - جماعي & المحاضرة & التعاوني & 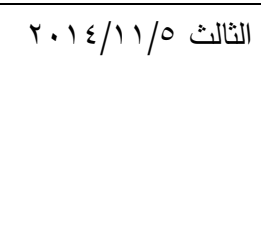 \\
\hline ه و دقيقة & فردي - جماعي & المناقشتة التراضرة & الذهني والخرائط الذهنية & 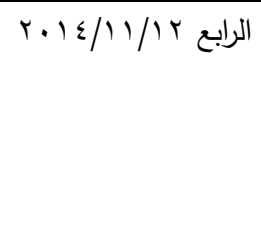 \\
\hline ه دقيقة & فردي - جماعي & والتدريس المصغرة والمناقثة & 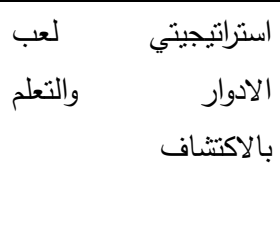 & الخامس \\
\hline ه 9 دقيقة & فردي - جماعي & والتدريس المصغرة والمناقثة & المثراتيجية & $11 / r_{1}$ \\
\hline . 9 دقيقة & فردي - جماعي & المحاضرة & استراتيجيتي العرض & 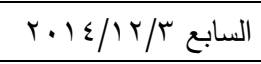 \\
\hline
\end{tabular}




\begin{tabular}{|c|c|c|c|c|c|}
\hline & مصنيق & & والتدريس | & الثفهي والالعاب & \\
\hline • 9 دقيقة & 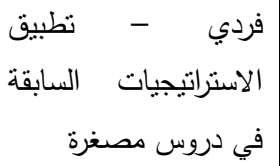 & المصغر & والتريس & دروس تدريبية & الثامن \\
\hline • 9 دقيقة & فردي & المصغر & والتريس & دروس تدريبية & 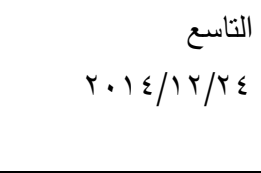 \\
\hline • 9 دقيقة & 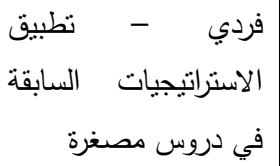 & المصغر & والتريس & دروس تدريبية & 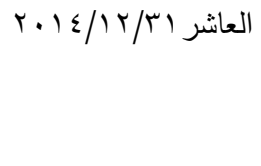 \\
\hline . 9 دقيقة & 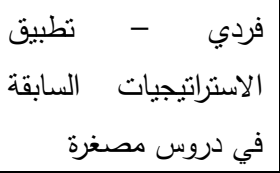 & المصغر & والتناقيسة & دروس تدريبية & عشر الحادي $10 / 1 /$. ب r \\
\hline • 9 دقيقة & في فردي & المصغر & والتدريس & دروس تدريبية & 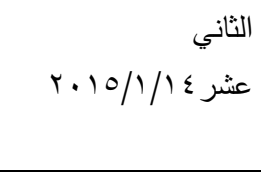 \\
\hline • 9 دقيقة & 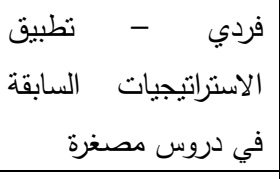 & المغز & والتدريس & دروس تدريبية & عشر الثالث \\
\hline • 9 دقيقة & فردي & المصغر & والتشناقشة & دروس تدريبية & 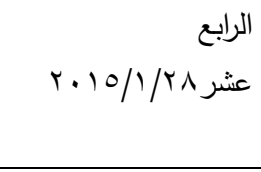 \\
\hline
\end{tabular}

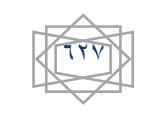


لتطبيق التجربة تم الاستفادة من تواجد الباحثة مع طلبتها في قسم الحاسبات حيث كانت الباحثة مشرفة

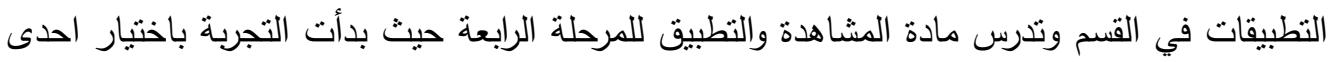
الثعب الثلاثة عشوائيا لتمثل المجموعة التجريبية وشعبة اخرى لتمنل المجموعة الضابطة .

اجراءات الضبط: تم ضبط المتغيرات الاتية والتي من المككن ان تؤثر في نتائج البحث ولم يكن

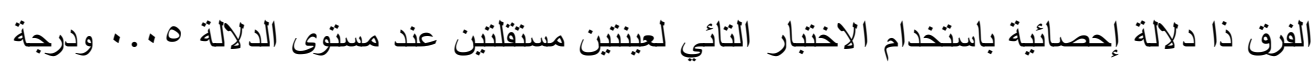

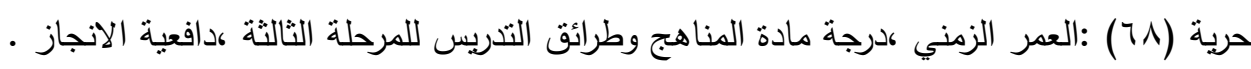

وللتأكد من السلامة الخارجية للتصميم التجريبي تم ما يأتي :

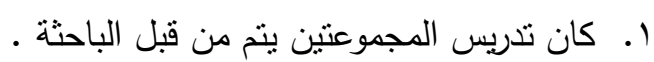

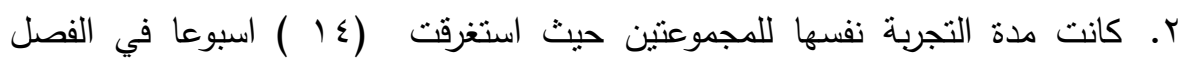

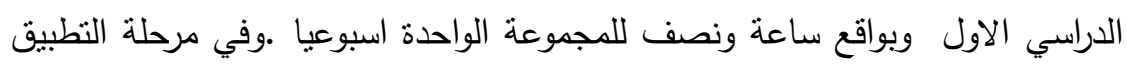

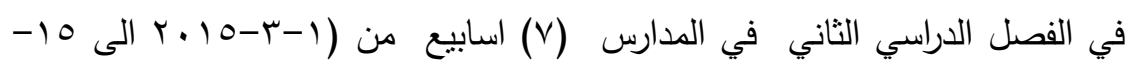

$$
(r \cdot 10-\varepsilon
$$

وتابعت الباحثة طلبتها قبل التطبيق وبعده وفي اثثاء التطبيق وكانت المتابعة من خلال زيارتهم واحيانا

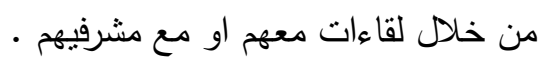

تنفيذ البرنامج للمجموعة التجريبية وتم ذلك كما يأتي :

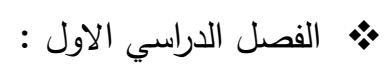

توزيع البرنامج على طلبة المرحلة الرابعة في المجموعة التجريبية( طلبة التربية العطلية) .

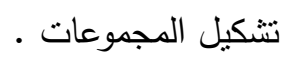

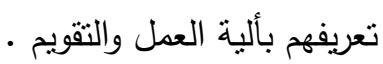
تنفيذ الانشطة.

تصوير الدروس الدصغرة التي ينفذها طلبة المجموعة التجريبية التي تتضمن التدريس

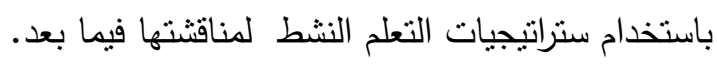




\section{العـــــــد الثاني والعشرون}

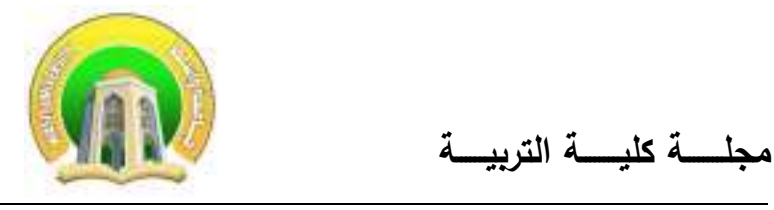 \\ • تقديم التغذية الراجعة اثناء التطبيق الفردي .} و وبانتهاء تدريب جميع الطلبة في الدجموعة ينتهي الفصل الدراسي الاول.

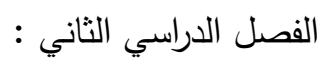

متابعة طلبة التربية العملية في المجموعة التجريبية أثناء تطبيقهم في مدارسهر من خلال المقابلة الفردية

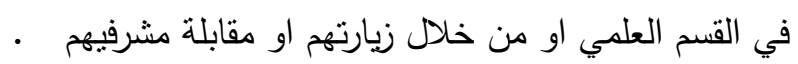

\section{المجموعة الضابطة :}

اعطاء محاضرات نظرية من قبل الباحثة نفسها عن التخطيط السنوي واليومي ومهارات التدريس الصفية وتقديم عرض سريع لطرائق تدريس الرياضيات التي سبق ان درسها في في فئي

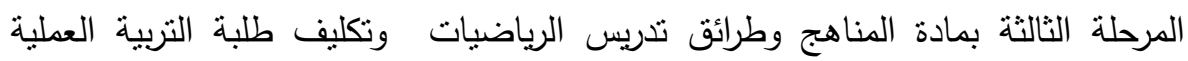

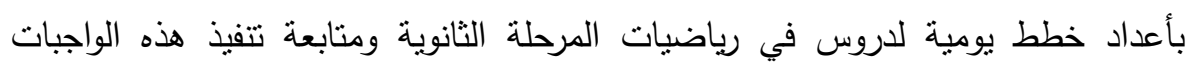

$$
\text { وتقديم تغذية راجعة لتقويم مسارهم • ( الاسبوع الاول والثاني ) }
$$

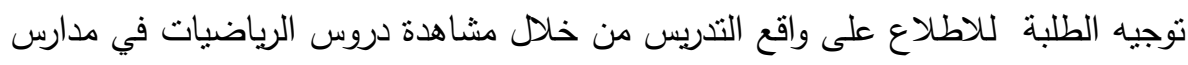

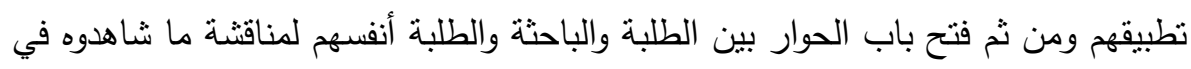
المدرسة من مواقف تدريسية وتربوية وتقييم الددرس من خلال استمارة التقييم التقليدية

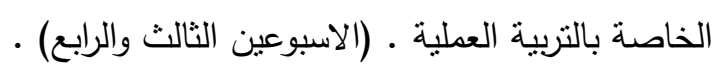

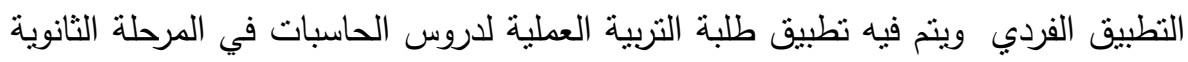

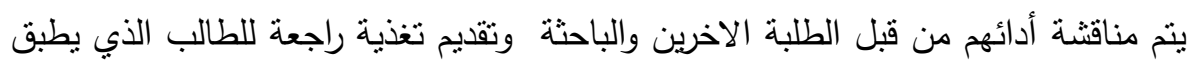

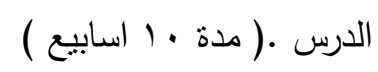

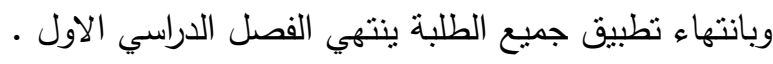
الفصل الدراسي الثناني :

متابعة طلبة التربية العملية في المجموعة الضابطة أثناء تطبيقهم في مدارسهم من خلد المقابلة

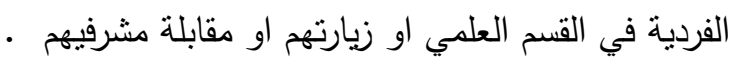




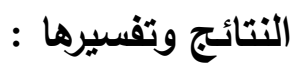

ولتحقيق الهدف الاول : ولقياس مدى توافر فقرات المقياس الممثلة لدوافع الانجاز لدى الطالب من

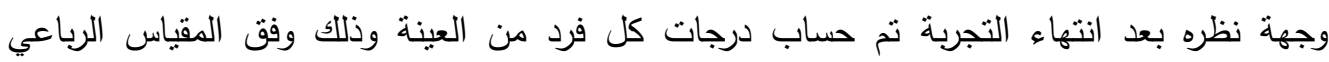

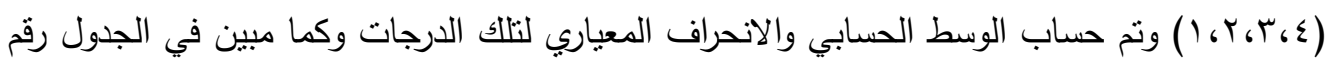

$$
\text { جدول (r) }
$$

نتائج الاختبار التائي لمعرفة دلالة الفرق بين متوسطي درجات المجموعتين التجريبية والضابطة في مقياس دافعية الانجاز

\begin{tabular}{|c|c|c|c|c|c|c|c|}
\hline \multirow{2}{*}{ الدلالة 0.05 مستوى } & \multicolumn{2}{|c|}{ القيمة التائية } & \multirow{2}{*}{ الحرية } & \multirow{2}{*}{ الانحراف } & \multirow{2}{*}{ الحسابي } & \multirow{2}{*}{ العينة } & \multirow{2}{*}{ للجموعة } \\
\hline & الجدولية & المحسوبة & & & & & \\
\hline \multirow{2}{*}{ دالة إحصائياً } & \multirow{2}{*}{ r } & \multirow{2}{*}{$0 . .7$} & \multirow{2}{*}{71} & $1 . .1 \varepsilon$ & MY.V & ro & التجريبية \\
\hline & & & & 1.17 & 1.1 .7 & ro & الضابطة \\
\hline
\end{tabular}

ويتضح من الجدول تفوق المجموعة التجريبية في درجات مقياس دافعية الانجاز وهذا قد

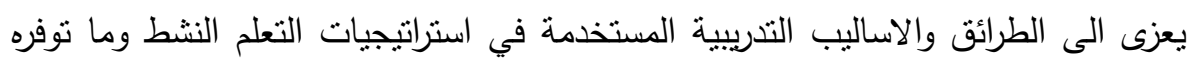

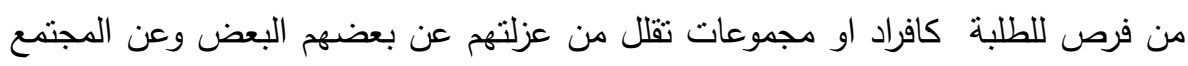

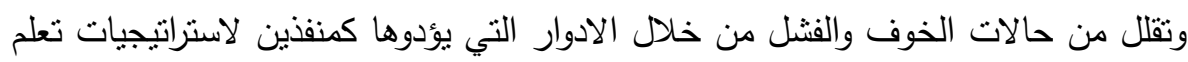

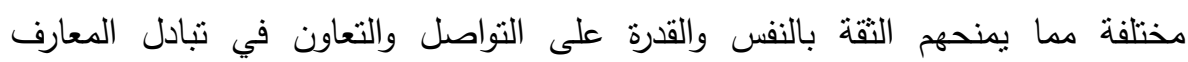

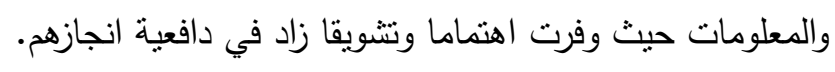




\section{مجلــــة كليــــة التربيــــة}

ولتحقيق الهدف الثاني : ولقياس مدى نوافر فقرات بطاقة الملاحظة الممثلة لمهارات التثريس لدى الطالب من وجهة نظر مشرفيهم تم حساب درجات كل فرد من العينة وذلك وفق المقياس الثلاثي

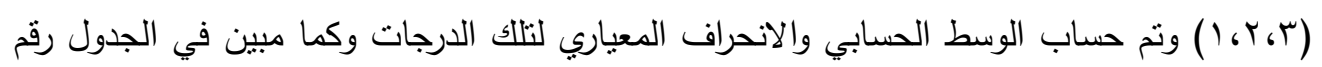

\section{جدول (צ)}

نتائج الاختبار التائي لمعرفة دلالة الفرق بين منتسطي درجات المجموعتين التجريبية والضابطة في بطاقة مهارات التدريس

\begin{tabular}{|c|c|c|c|c|c|c|c|}
\hline \multirow{2}{*}{ مستوى 0. . . . لالة } & \multicolumn{2}{|c|}{ القيمة التائية } & \multirow{2}{*}{ الحربة } & \multirow{2}{*}{ الانحراف } & \multirow{2}{*}{ الوسط } & \multirow{2}{*}{ العينة } & \multirow{2}{*}{ المجموعة } \\
\hline & الجدولية & المحسوبة & & & & & \\
\hline \multirow{2}{*}{ دالة إحصائياً } & \multirow{2}{*}{$1.77 \vee 7$} & \multirow{2}{*}{ r.VT } & \multirow{2}{*}{71} & $9 . .1$ & 10.V $\leqslant$ & ro & التجريبية \\
\hline & & & & $1 \leq .9 \leq$ & VV.T & o & الضابطة \\
\hline
\end{tabular}

ويتضح من الجدول تفوق المجموعة التجريبية في درجات بطاقة مهارات التريس ،وهذا قد يعزى الى الطرائق والاساليب التربيبة المستخدمة في استراتيجيات التعلم النشط وما توفره من فرص للطلبة في مناقثة افكارهم واظهار وعيهم بمهارات التدريس وتبادل المعلومات المتعلقة بها فيما بينهم من خلال مجموعاتهم كما توفر فرص اكبر للتقييم الذاتي والتقييم في مجموعات من خلال التغذية الراجعة مما يهيأ فرص اكبر لتحسين مستوى الاداء وتطويره

- ـ ولمقارنة اثز استراتيجيات التعلم النشط في دافعية الانجاز ومهارات التدريس لطلبة المجموعة التجربيية تم حساب قيمة معامل ارتباط بيرسون وباستخدام اختبار t لمعرفة دلالة معامل الارتباط بين الدرجات عند مستوى دلالة (0. . •) وكما مبين في الجدول رقم

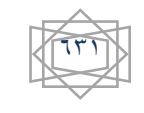




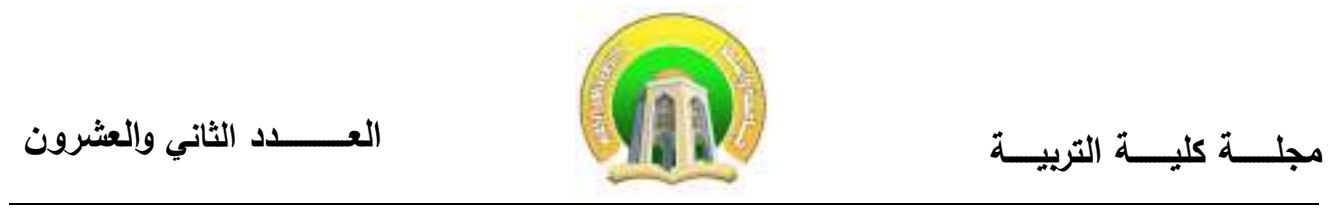

\section{جدول (•)}

دلالة معامل الارتباط لدرجات طلبة المجموعة التجريبية في

مقياس دافعية الانجاز ومهارات التدريس

\begin{tabular}{|c|c|c|c|c|c|}
\hline \multirow{2}{*}{ مستوى 0. . . . عند } & \multicolumn{2}{|c|}{ القيمةالتائية } & \multirow{2}{*}{ درجة الحرية } & \multirow{2}{*}{ قارتباط بيرسون } & \multirow{2}{*}{ حجم } \\
\hline & الجدولية & المحسوبة & & & \\
\hline دال احصائياً & $1.794 \leqslant$ & $\varepsilon . V_{0}$ & سץ & $.7 \varepsilon$ & ro \\
\hline
\end{tabular}

ويتضح من الجدول وجود علاقة ارتباطية ذات دلالة احصائية عند مسنوى دلالة ه . . بين درجات طلبة المجموعة التجريبية في مقياس دافع الانجاز وبطاقة ملاحظة مهارات التدريس ،اي ان ارتفاع مستوى دافعية الانجاز ينسجم مع ارتفاع مستوى مهارات التدريس وفق التعلم النشط .وهذا قد يعزى الى التفاعل الايجابي التي تتيحها استراتيجيات التعلم النشط فضلا عن التفاعل والتواصل بين الطالب والباحثة وبين الطلبة انفسهم الذي توفره استراتيجيات التعلم النشط اثثاء المحاضرات والجلسات التدربيية . 
الاستنتاجات : (1)

1- من خلال عرض النتائج يتضح وجود اثر لاستراتيجيات التعلم النشط في دافعية انجاز

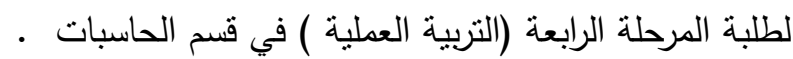
ץ- وجود اثز لاستراتيجيات التعلم النشط في مهارات تدريس طلبة المرحلة الرابعة (التربية

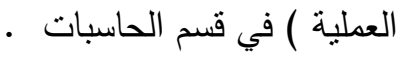
التوصيات : (1) - n

1- ضرورة استخدام استراتيجيات التعلم النشط المختلفة لتدريب طلبة التربية العملية في قسم الحاسبات والاقسام العلمية الاخرى لاثره في رفع مستوى دافعية انجازهم ومهارات تدريسهم • ץ- ضرورة ان تتضمن مادة المناهج وطرائق تدريس الرياضيات التي يدرسها الطالب في المرحلة الثالثة على ساعات للتطبيق العملي والمشاهدة لدروس نموذجية تثضن استراتيجيات حديثة في مدارس متميزة في المرحلة الثانوية ولمدة يوم واحد اسبوعيا . r- اقامة ورش عمل ودورات تضضمن استراتيجيات تدريس حديثة مختلفة مثل استراتيجيات التعلم النشط وتدربب المدرسين عليها اثثاء الخدمة . ع - استخدام مقياس دافعية الانجاز وبطاقة ملاحظة مهارات التدريس التي أعدت لأغراض هذا البحث في تقويم مدرسي الحاسبات في المراحل كافة من قبل مدراء المدارس والمشرفيين • التربوبين

1- التذريب على استراتيجيات التعلم النشط ودراسة اثرها في تحصيل موضوعات علمية معينة لطلبة قسم الحاسبات في كليات التربية. r- تطبيق مقياس دافعية الانجاز وبطاقة ملاحظ مهارات التدريس المعد لهذه الدراسة وقياس

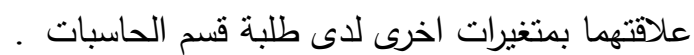

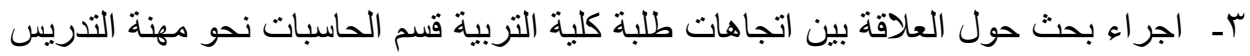
وبين دافعية انجاز هم . 


\section{العـــــــدد الثاني والعشرون}

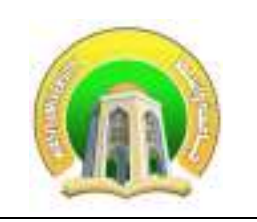

\section{مجلـــة كليـــة التربيــة}

المصادر :

- ابو رياش،حسين محمد واخرون (9. . ب)،اصول استراتيجيات التعلم والتعليم ،دار الثقافة للنشر والتوزيع ،عمان ، الاردن.

- ابو المعاطي، وليد محمد (11 (1) ،مهارات التعلم ودافعية الانجاز كمتغيرات وسيطة بين التفاعل الصفي والاستدلال

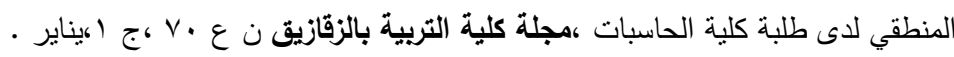

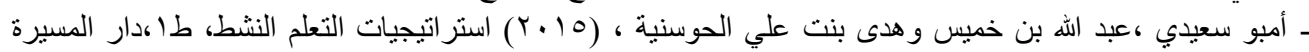

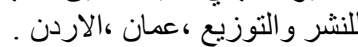

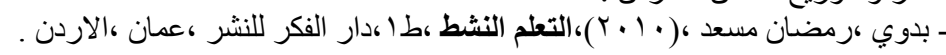

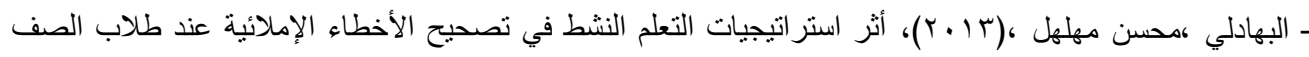

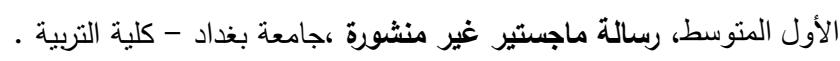

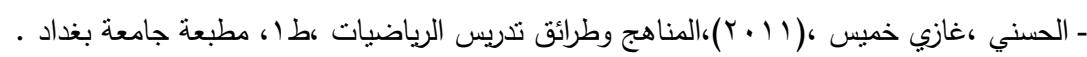

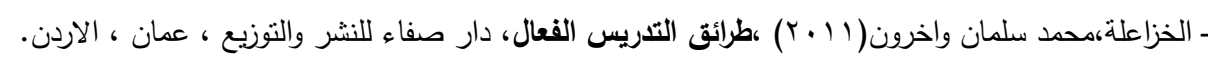

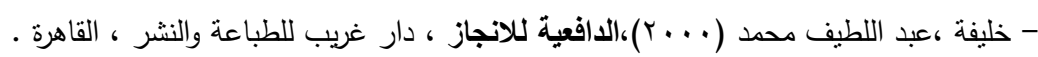

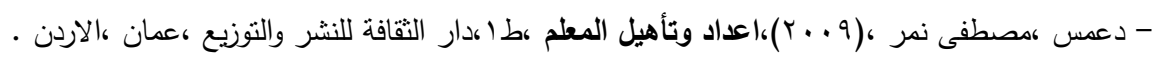

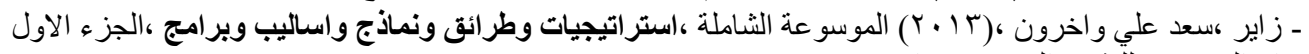

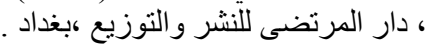

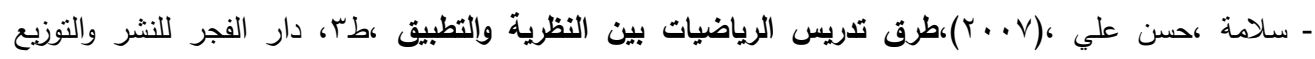
القاهرة.

ـالسكارنة ،بلال خلف (1) ب (1) ،تصميم البرامج التدريبية (ط ) ،دار المسيرة للنشر والتوزيع ،عمان ، الاردن.

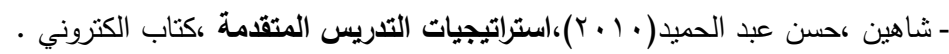

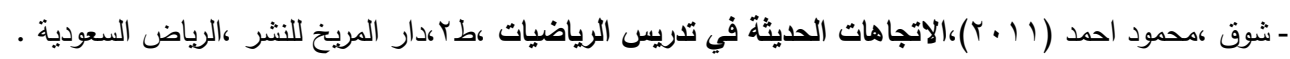

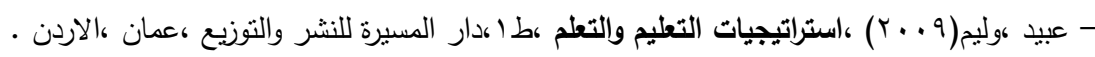

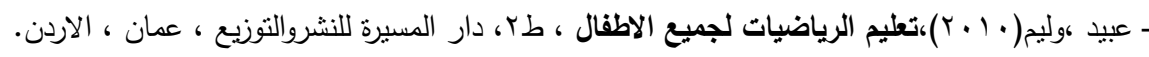

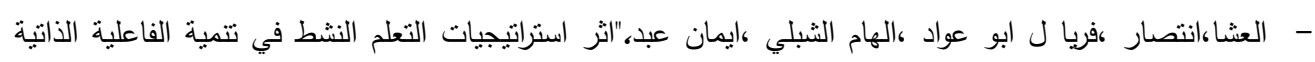

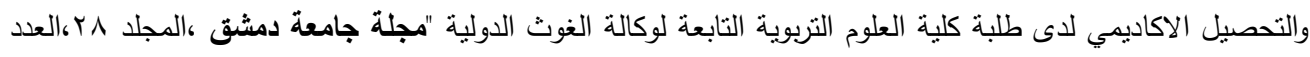

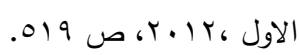

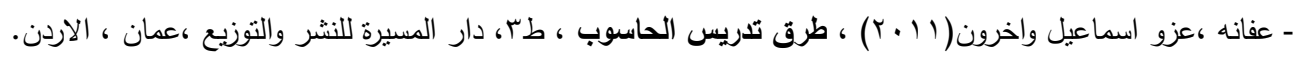

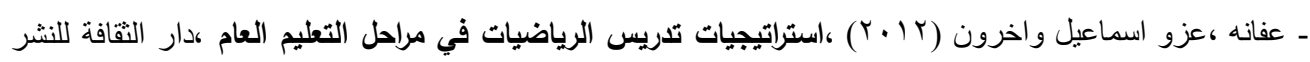
والتوزيع ، عمان ، الاردن.

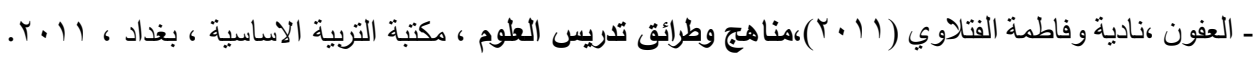

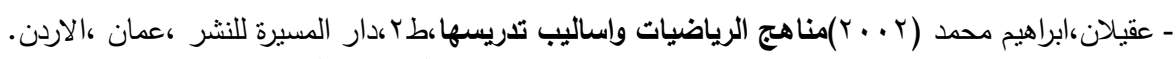

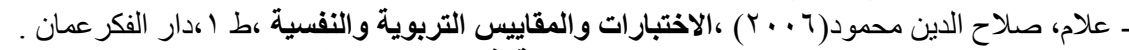

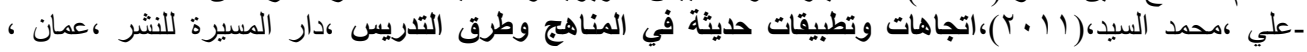
الاردن. 


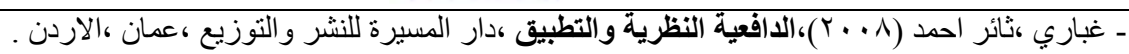

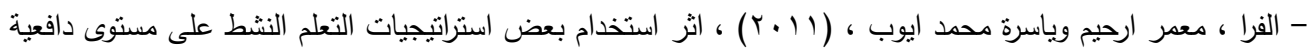

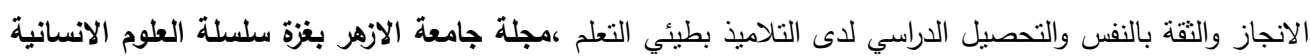

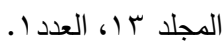

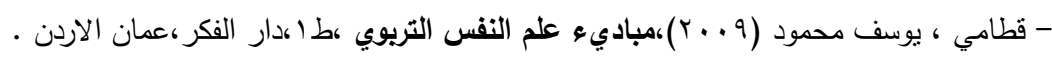

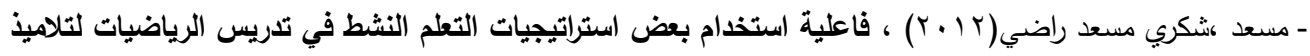
المرحلة

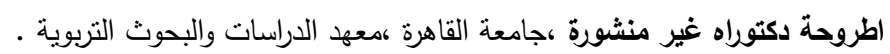

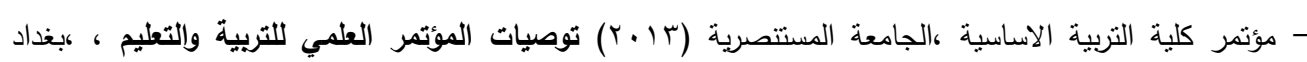

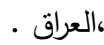

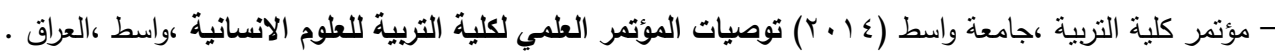

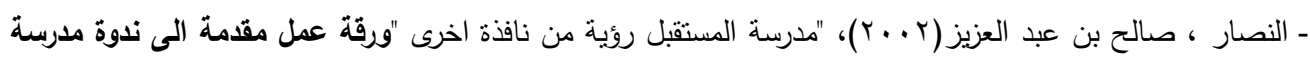

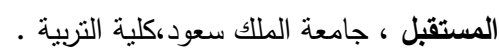

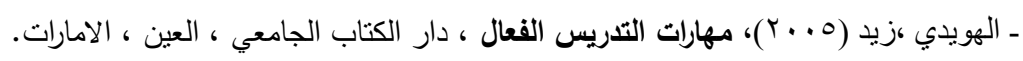

- Bonwell ,c.c\&Eison ，J,A(1991) - Activ Learning Creating excitement in the classroom, - Eric Clearinghouse on Higher Education,Washington,DC.

- Carroll, L. \& Leander, S. (2001). Improve Motivation through the

Use of Active Learning Strategies. Unpublished Master

Dissertation. Saint Xavier University .

NCATE. (1999). NCATE 2000 standards. Washington

DC. Retrieved in June 20, 2009, from website:

www.ncate.org. 


\section{مجلـــة كليــــة التربيـــة}

ملحق (1)

مقياس دافعية الانجاز

\begin{tabular}{|c|c|c|c|c|}
\hline 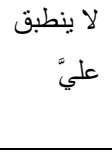 & قليّل بُشكل & 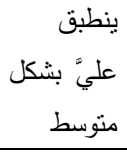 & عبنيَ بشكل & 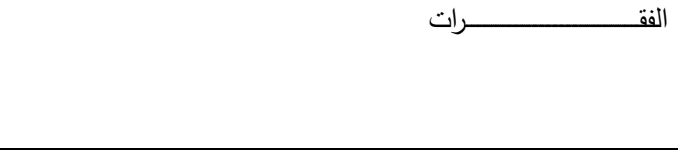 \\
\hline & & & & 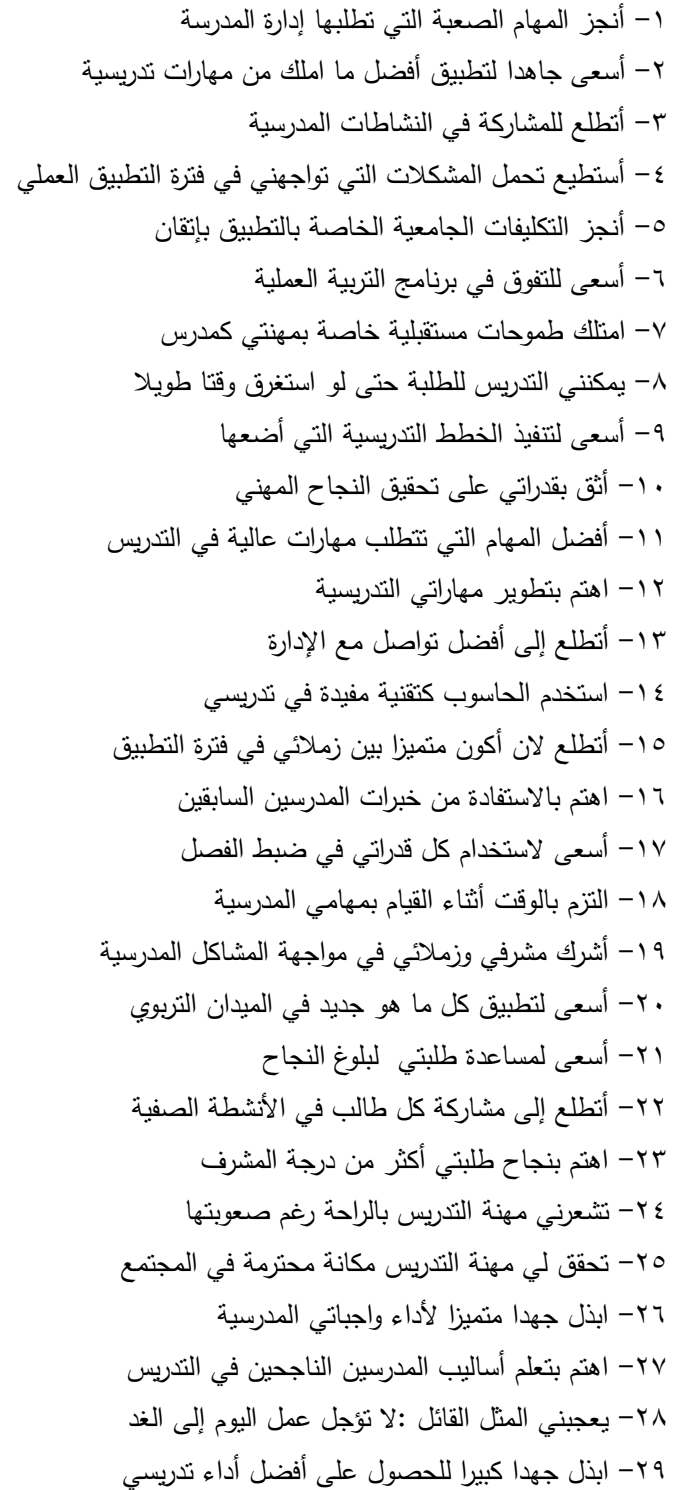 \\
\hline
\end{tabular}




\section{مجلــــة كليــــة التربيــــة}

ملحق (r)

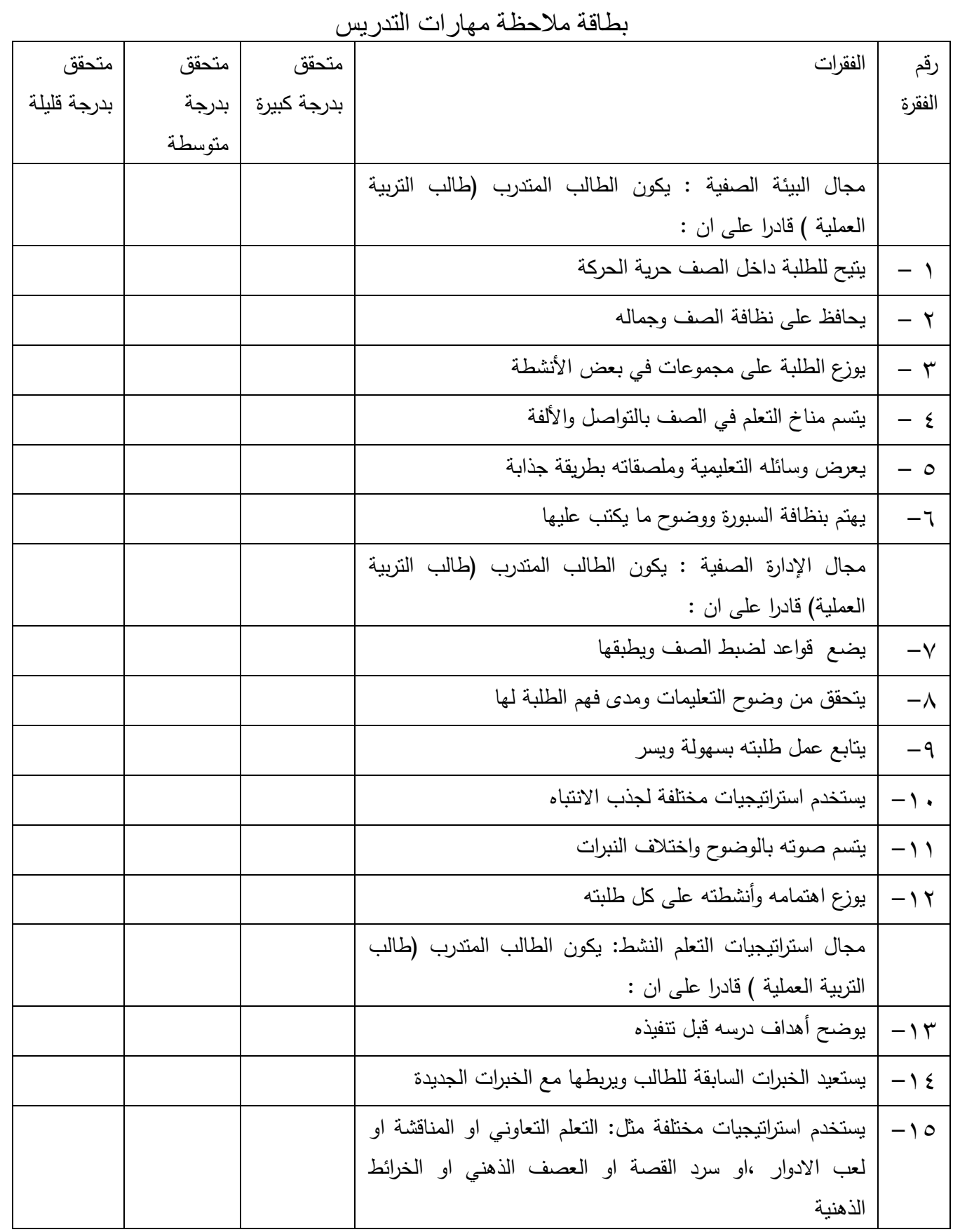




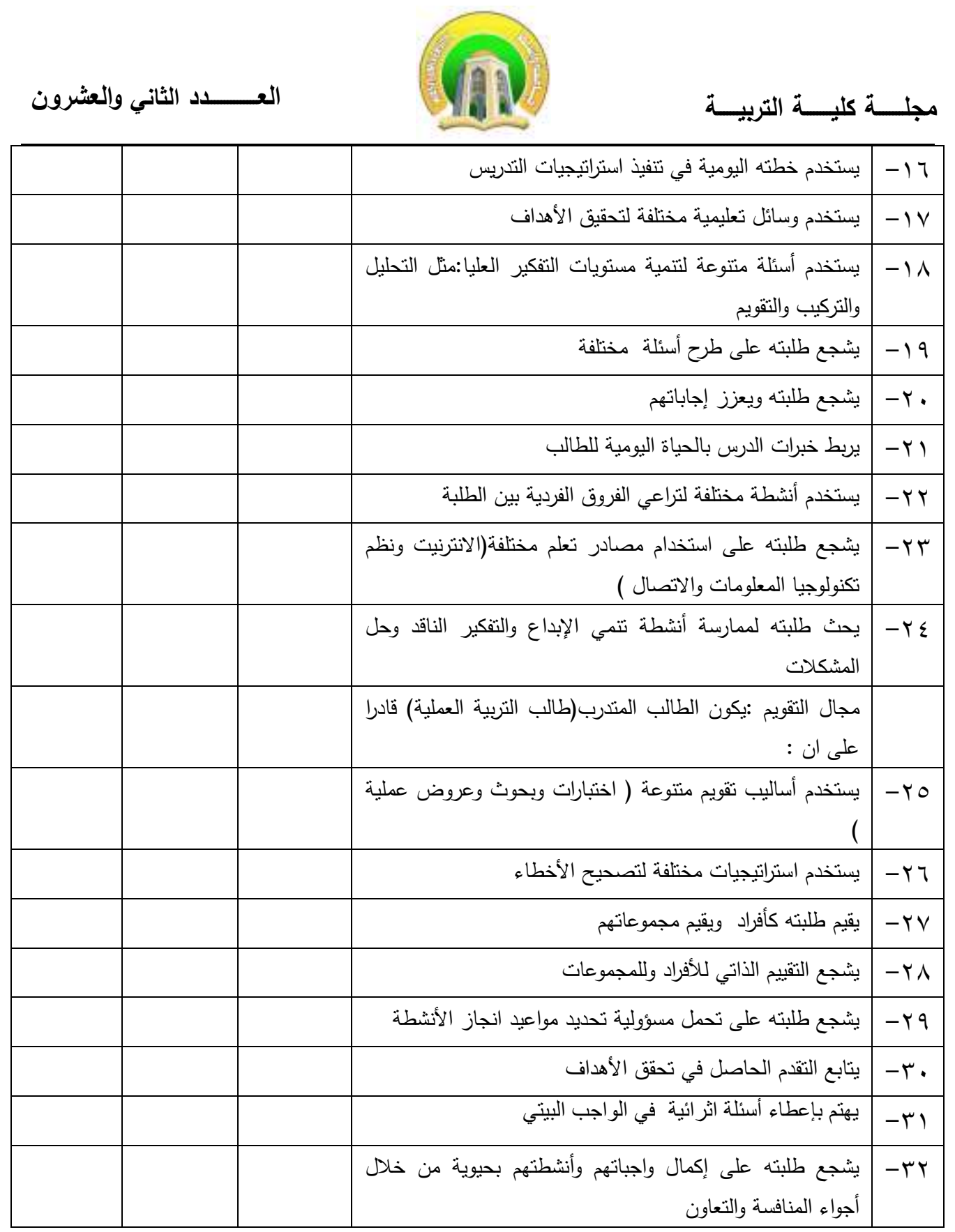

